\title{
ПРИЯОЖЕНИЕ
}

\section{Сравнительный анализ проповеди А.-П. Стенди и перевода К. П. Победоносцева: разночтения и комментарии}

\begin{tabular}{|c|c|c|c|}
\hline $\begin{array}{c}\text { Проповедь Стенли } \\
\text { (на англ. языке) }\end{array}$ & $\begin{array}{c}\text { Перевод } \\
\text { К. П. Победоносцева } \\
\text { (Гражданинб. } 1874 . \\
\text { № 3. С. 78-81) }\end{array}$ & $\begin{array}{c}\text { Редакционное } \\
\text { изложение } \\
\text { (Гражданинб. 1874. } \\
\text { № 2. С. 37-39) }\end{array}$ & Комментарии \\
\hline & $\begin{array}{c}\text { ПРОПОВъДь, } \\
\text { сказанная г. Стенлеемъ, } \\
\text { деканомъ Вестминстер- } \\
\text { скимъ, въ англійской } \\
\text { церкви въ С.-Петербургъ } \\
6 \text { (18) января. }\end{array}$ & $\begin{array}{c}\text { ПРОПОВъдь, } \\
\text { сказанная г. Стенлеемъ, } \\
\text { деканомъ вестминстер- } \\
\text { скимъ, въ англійской } \\
\text { церкви въ С.-Петербургъ } \\
6 \text { (18) января. }\end{array}$ & \\
\hline & & $\begin{array}{l}\text { Получивъ позволеніе } \\
\text { отъ почтеннаго проповъд- } \\
\text { ника напечатать въ пере- } \\
\text { водъ его проповъдь, мы } \\
\text { помъстимъ ее въ слъдую- } \\
\text { щемъ № нашего изданія. } \\
\text { Сегодня же передаемъ } \\
\text { только ея содержаніе, } \\
\text { и приводимъ нъкоторыя } \\
\text { изъ нея мъста. } \\
\text { Текстомъ своей бе- } \\
\text { съды проповъдникъ из- } \\
\text { бралъ слово изъ Евангелія } \\
\text { Іоанна о бракъ въ Канъ } \\
\text { Галилейской. Событіе это } \\
\text { проповъдникъ разсматри- } \\
\text { ваетъ съ двухъ сто- } \\
\text { ронъ, во первыхъ, какъ } \\
\text { проявленіе славы Божіей, } \\
\text { во вторыхъ, въ его осо- } \\
\text { бенномъ примъненіи къ } \\
\text { настоящимъ обстоятель- } \\
\text { ствамъ. } \\
\text { Проповъдникъ, дълая } \\
\text { описаніе Каны Галилей- } \\
\text { ской, говоритъ: }\end{array}$ & \\
\hline $\begin{array}{l}\text { ST-JOHN. II. 1.2. } \\
\text { And the third day three } \\
\text { was a marriage in Cana of } \\
\text { Galilee, and the mother of } \\
\text { Jesus was there and both } \\
\text { Jesus was called and his dis- } \\
\text { ciples to the marriage }\end{array}$ & $\begin{array}{r}\text { «И въ третій день } \\
\text { бысть бракъ въ Канъ } \\
\text { Галилейстьй и бъ Мати } \\
\text { Іисусова ту. Званъ же } \\
\text { бысть Іисусь и ученицы } \\
\text { Его на бракъ.» } \\
\text { Еванг. отъ Іоанна. } \\
\text { Гл. ІІ. Ст. } 1,2 .\end{array}$ & & \\
\hline
\end{tabular}




\begin{tabular}{|c|c|c|c|}
\hline $\begin{array}{c}\text { Проповедь Стенли } \\
\text { (на англ. языке) }\end{array}$ & $\begin{array}{c}\text { Перевод } \\
\text { К. П. Победоносцева } \\
\text { (Гражданинъ. 1874. } \\
\text { № 3. С. 78-81) }\end{array}$ & $\begin{array}{c}\text { Редакционное } \\
\text { изложение } \\
\text { (Гражданинъ. 1874. } \\
\text { № 2. С. 37-39) }\end{array}$ & Комментарии \\
\hline $\begin{array}{l}\text { These words are taken } \\
\text { from the Gospel which has } \\
\text { been read in every church in } \\
\text { England on this, as it is there } \\
\text { observed, the Second Sun- } \\
\text { day after Epiphany, and, as } \\
\text { they are thus read, will recall } \\
\text { the hearts of many an En- } \\
\text { glish congregation in state- } \\
\text { ly Cathedral and humble } \\
\text { village church to the events } \\
\text { which occupy the thoughts } \\
\text { of all in this great Northern } \\
\text { capital. It has also been read } \\
\text { as the Second Lesson of the } \\
\text { Epiphany, according to the } \\
\text { Old Style, in the service of } \\
\text { this afternoon. }\end{array}$ & $\begin{array}{l}\text { Это мъсто изъ Свя- } \\
\text { щеннаго Писанія было } \\
\text { прочтено сегодня на день } \\
\text { Богоявленія (по старому } \\
\text { стилю). Оно будетъ про- } \\
\text { чтено и во всъхъ церквахъ } \\
\text { Англіи, какъ Евангеліе } \\
\text { втораго Воскресенія посль } \\
\text { Богоявленія (по новому } \\
\text { стилю), и сколько сердецъ } \\
\text { изъ англійской паствы, } \\
\text { внимая ему вездъ, какъ въ } \\
\text { величественномъ соборъ, } \\
\text { такъ и въ смиренной сель- } \\
\text { ской церкви, перенесутся } \\
\text { мыслію къ тому событію } \\
\text { на которомъ сосредо- } \\
\text { точено вниманіе всьхъ } \\
\text { здъсь, въ великой столиць } \\
\text { Съвера. }\end{array}$ & & 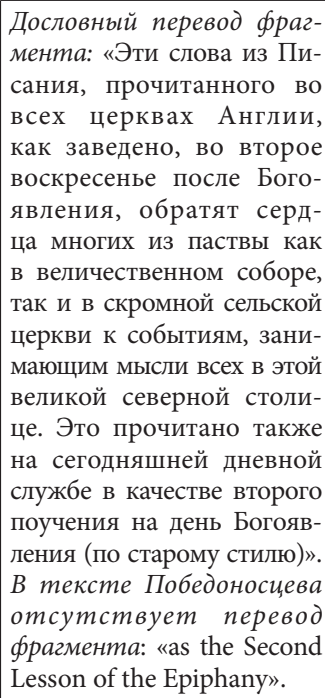 \\
\hline $\begin{array}{l}\text { And that same Gospel will } \\
\text { be read again in the service } \\
\text { to be celebrated, as we trust }{ }^{2} \text {, } \\
\text { in the Imperial Chapel, be- } \\
\text { fore the week is closed. }\end{array}$ & $\begin{array}{l}\text { То же самое Евангеліе } \\
\text { будетъ снова прочтено на } \\
\text { Богослуженіи которое бу- } \\
\text { детъ совершено въ Двор- } \\
\text { цовой церкви, съ Божіей } \\
\text { помощію, въ концъ этой } \\
\text { недъли. }\end{array}$ & & $\begin{array}{l}\text { Дословный перевод фраг- } \\
\text { мента: «То же самое Писа- } \\
\text { ние будет прочитано снова } \\
\text { во время богослужения, } \\
\text { как мы надеемся, в Импе- } \\
\text { раторской церкви (капел- } \\
\text { ле), до конца недели». } \\
\text { В переводе Победоносиева } \\
\oint \text { раза «аs we trust» звучит } \\
\text { «сь Божіей помощію». }\end{array}$ \\
\hline $\begin{array}{l}\text { Such a joint prominence } \\
\text { given to this sacred passage } \\
\text { in both Churches by this } \\
\text { coincidence makes it almost } \\
\text { impossible to select any } \\
\text { other topic for our thoughts } \\
\text { on this occasion. Let us take } \\
\text { it in its several aspects - } \\
\text { first, as the example and } \\
\text { likeness of all such events } \\
\text { in all times; and then as } \\
\text { suggestive of the more spe- } \\
\text { cial application to our own } \\
\text { circumstances. }\end{array}$ & $\begin{array}{l}\text { Такое особенное зна- } \\
\text { ченіе, приданное этому тек- } \\
\text { сту Священнаго Писанія, } \\
\text { своимъ совпаденіемъ за- } \\
\text { ставляетъ насъ, сосредо- } \\
\text { точивъ на немъ все наше } \\
\text { вниманіе, выбрать его се- } \\
\text { годня предметомъ нашихъ } \\
\text { вечернихъ размышленій. } \\
\text { Разсмотримъ же мы этотъ } \\
\text { текстъ съ разныхъ его сто- } \\
\text { ронъ: во первыхъ какъ } \\
\text { событіе увънчавшее собою } \\
\text { празднество Богоявленія } \\
\text { или знаменія Божіей } \\
\text { славы, а во вторыхъ въ } \\
\text { приложеніи его къ нашей } \\
\text { собственной жизни. }\end{array}$ & & $\begin{array}{l}\text { Дословный перевод фраг- } \\
\text { мента: «Столь большое } \\
\text { внимание, уделенное это- } \\
\text { му отрывку из Священно- } \\
\text { го Писания обеими церк- } \\
\text { вами, своим совпадением } \\
\text { делает почти невозмож- } \\
\text { ным выбор какой-либо } \\
\text { иной темы для наших раз- } \\
\text { мышлений в данной си- } \\
\text { туации. Давайте разберем } \\
\text { его с разных точек зрения: } \\
\text { во-первых, в качестве при- } \\
\text { мера и сходства всех по- } \\
\text { добных празднеств во все } \\
\text { времена, а во-вторых, в ка- } \\
\text { честве намека на примене- } \\
\text { ние его к нашим собствен- } \\
\text { ным обстоятельствам». }\end{array}$ \\
\hline
\end{tabular}

${ }^{1}$ Синим ивветом выделены фрагменты текста, отсутствующие в переводе Победоносиева.

${ }^{2}$ Красно-коричневым иветом выделены разночтения между оригиналом и переводом Победоносиева. 


\begin{tabular}{|c|c|c|c|}
\hline $\begin{array}{c}\text { Проповедь Стенли } \\
\text { (на англ. языке) }\end{array}$ & $\begin{array}{c}\text { Перевод } \\
\text { К. П. Победоносцева } \\
\text { (Гражданинъ. 1874. } \\
\text { № 3. С. 78-81) }\end{array}$ & $\begin{array}{c}\text { Редакционное } \\
\text { изложение } \\
\text { (Гражданинъ. 1874. } \\
\text { № 2. С. 37-39) }\end{array}$ & Комментарии \\
\hline $\begin{array}{l}\text { "There was a marriage } \\
\text { in Cana of Galilee." Let me } \\
\text { for a moment transport you } \\
\text { from the dark skies and fro- } \\
\text { zen rivers of the North to } \\
\text { the brilliant sunshine, the } \\
\text { luxuriant glades and for- } \\
\text { ests of Palestine. }\end{array}$ & $\begin{array}{l}\text { І. «И въ третій день } \\
\text { бысть бракъ въ Канъ } \\
\text { Галилейстъй.» Забывъ на } \\
\text { минуту туманное небо } \\
\text { и закованныя въ ледъ } \\
\text { рбки Съвера, перенесемся } \\
\text { въ облитую солнцемъ Па- } \\
\text { лестину съ ея роскошны- } \\
\text { ми дубравами. }\end{array}$ & & $\begin{array}{l}\text { Фраза «luxuriant glades } \\
\text { and forests of Palestine» } \\
\text { буквально: «роскошными } \\
\text { пролесками и лесами». }\end{array}$ \\
\hline $\begin{array}{l}\text { "Cana of Galilee" was, } \\
\text { and is still, a village han- } \\
\text { ging on the rocky edge of } \\
\text { the hills that overlook one } \\
\text { of the rich upland plains } \\
\text { which the traveller pas- } \\
\text { ses between Nazareth and } \\
\text { Capernaum. On that level } \\
\text { meadow waved, and still } \\
\text { wave, the tall reeds or } \\
\text { canes whence doubtless it } \\
\text { derives its name of Cana. } \\
\text { On the side of the hill was, } \\
\text { and still is, a deep well of } \\
\text { abundant water. Amid the } \\
\text { gardens and enclosures } \\
\text { there was a well-known fig } \\
\text { tree, spreading out its broad } \\
\text { green leaves, under which, } \\
\text { but a few days before, had } \\
\text { sat a native of that village, } \\
\text { Nathaniel of Cana, medi- } \\
\text { tating over secrets of his } \\
\text { heart, noticed by One of } \\
\text { whom he was not thinking, } \\
\text { but who was thinking and } \\
\text { caring for him, more than } \\
\text { he cared for himself. Behind } \\
\text { the village, far up into the } \\
\text { bosom of the hills, opens } \\
\text { a wild rocky dell, teeming } \\
\text { with tangled verdure and } \\
\text { bright, flowering shrubs - } \\
\text { a glen as romantic as ever } \\
\text { witnessed the first glad hopes } \\
\text { of early life or the plighted } \\
\text { troth of innocent love. }\end{array}$ & 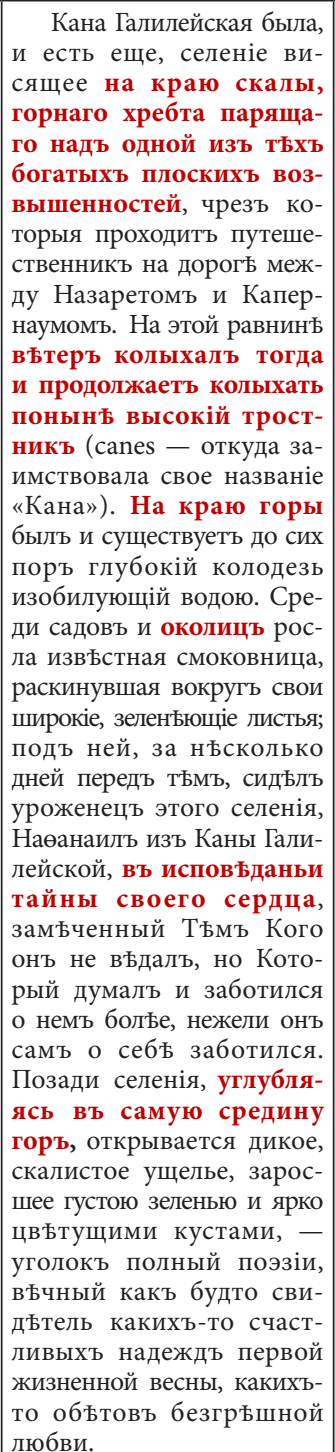 & $\begin{array}{l}\text { «Кана Галилейская была, } \\
\text { и есть еще, селеніе вися- } \\
\text { щее на краю скалы, горна- } \\
\text { го хребта парящаго надъ } \\
\text { одной изъ тьхъ богатыхъ } \\
\text { плоскихъ возвышенностей, } \\
\text { чрезъ которыя прохо- } \\
\text { дитъ путешественникъ на } \\
\text { дорогъ между Назаретомъ } \\
\text { и Капернаумомъ. На этой } \\
\text { равнинъ вътерь колыхаль } \\
\text { тогда и продолжаетъ ко- } \\
\text { лыхать понынъ высокій } \\
\text { тростникъ (сапеs - от- } \\
\text { куда заимствовала свое } \\
\text { названіе «Кана»). На краю } \\
\text { горы былъ и существуетъ } \\
\text { до сих поръ глубокій ко- } \\
\text { лодезь изобилующій во- } \\
\text { дою. Среди садовъ и око- } \\
\text { лицъ росла извьстная } \\
\text { смоковница, раскинувшая } \\
\text { вокругъ свои широкіе, } \\
\text { зеленъющіе листья; подъ } \\
\text { ней, за нъсколько дней } \\
\text { передъ тьмъ, сидъль } \\
\text { уроженецъ этого селенія, } \\
\text { Наөанаилъ изъ Каны Гали- } \\
\text { лейской, въ исповъданьи } \\
\text { тайны своего сердца, } \\
\text { замъченный Тъмъ Кого } \\
\text { онъ не въдалъ, но Кото- } \\
\text { рый думаль и заботился } \\
\text { о немъ болъе нежели онъ } \\
\text { самъ о себъ заботился. } \\
\text { Позади селенія, углубля- } \\
\text { ясь въ самую средину } \\
\text { горъ, открывается дикое, } \\
\text { скалистое ущелье, за- } \\
\text { росшее густою зеленью } \\
\text { и ярко цвътущими куста- } \\
\text { ми, - уголокъ полный } \\
\text { поэзіи, въчный какъ буд- } \\
\text { то свидътель какихъ-то } \\
\text { счастливыхъ надеждъ } \\
\text { первой жизненной вес- } \\
\text { ны, какихъ-то обьтовъ } \\
\text { безгрбшной любви. }\end{array}$ & $\begin{array}{l}\text { Дословныц перевод фраг- } \\
\text { мента: “Кана Галилей- } \\
\text { ская” была и остается } \\
\text { селением на гористых } \\
\text { склонах холмов, которые } \\
\text { смотрят на одну из бога- } \\
\text { тых плоских возвышен- } \\
\text { ностей. На той равнине } \\
\text { шумел и до сих пор шумит } \\
\text { (качается) высокий трост- } \\
\text { ник, от которого и про- } \\
\text { изошло, без сомнения, } \\
\text { название Кана. На склоне } \\
\text { холма находился тогда } \\
\text { и находится сейчас глу- } \\
\text { бокий колодец, полный } \\
\text { воды. Среди садов и ого- } \\
\text { родов росла известная } \\
\text { смоковница (фиговое де- } \\
\text { рево), раскинувшая свои } \\
\text { широкие зеленые листья, } \\
\text { под которой несколькими } \\
\text { днями ранее сидел житель } \\
\text { этого селения, Натаниэль } \\
\text { из Каны, предаваясь раз- } \\
\text { мышлениям о тайнах сво- } \\
\text { его сердца, замеченный } \\
\text { Тем, о котором он не ду- } \\
\text { мал, но Кто думал и забо- } \\
\text { тился о нем больше, чем } \\
\text { он сам заботился о себе. } \\
\text { За селением, дальше вверх } \\
\text { по холму, открывается } \\
\text { дикое, скалистое ущелье, } \\
\text { изобилующее густой зеле- } \\
\text { нью и ярко цветущими ку- } \\
\text { стами, - романтическое } \\
\text { ущелье, вечный свидетель } \\
\text { счастливых надежд начи- } \\
\text { нающейся жизни или обе- } \\
\text { щаний невинной любви». }\end{array}$ \\
\hline
\end{tabular}




\begin{tabular}{|c|c|c|c|}
\hline $\begin{array}{c}\text { Проповедь Стенли } \\
\text { (на англ. языке) }\end{array}$ & $\begin{array}{c}\text { Перевод } \\
\text { К. П. Победоносцева } \\
\text { (Гражданинъ. } 1874 . \\
\text { № 3. С. 78-81) }\end{array}$ & $\begin{array}{c}\text { Редакционное } \\
\text { изложение } \\
\text { (Гражданинъ. 1874. } \\
\text { № 2. С. 37-39) }\end{array}$ & Комментарии \\
\hline $\begin{array}{l}\text { In this happy and beau- } \\
\text { tiful village there was a mar- } \\
\text { riage feast. We know not } \\
\text { the names of the bridal pair; } \\
\text { but it is evident that the } \\
\text { occasion was a reunion of } \\
\text { the Holy Family and their } \\
\text { friends. Cana itself seems to } \\
\text { have become to them a kind } \\
\text { of second adopted home } \\
\text { after they left Nazareth and } \\
\text { before they settled at Caper- } \\
\text { naum. "The mother of Je- } \\
\text { sus was there". The mother } \\
\text { of the family. How much } \\
\text { is conveyed in that word! } \\
\text { Joseph, the natural head } \\
\text { and guardian of the house, } \\
\text { had, as it would seem, } \\
\text { been taken to his rest. } \\
\text { there were the sailors of the } \\
\text { the "beloved disciple"; there } \\
\text { He who would have seen } \\
\text { with such interest the on- } \\
\text { ward march of the family } \\
\text { over which he had so long } \\
\text { watched - he was absent. } \\
\text { But she who had so long } \\
\text { pondered over the thoughts } \\
\text { and deeds of the last thirty } \\
\text { years - she who then unit- } \\
\text { ed both parental feelings in } \\
\text { herself - she who had so } \\
\text { long been the centre of the } \\
\text { circle in which she moved, } \\
\text { gave her blessing to the sa- } \\
\text { cred gathering. "And Jesus } \\
\text { was called and His disci- } \\
\text { ples to the marriage." He } \\
\text { was invited and He came, } \\
\text { there }\end{array}$ & $\begin{array}{l}\text { Въ этомъ счастливомъ } \\
\text { и прекрасномъ селеніи } \\
\text { было брачное торжество. } \\
\text { Имя новобрачныхъ намъ } \\
\text { неизвъстно, но очевидно } \\
\text { на праздникъ этотъ со- } \\
\text { брались всъ члены Свя- } \\
\text { таго Семейства и друзья } \\
\text { ихъ. Должно предпола- } \\
\text { гать что Кана Галилей- } \\
\text { ская сдълалась для нихъ } \\
\text { какъ бы вторымъ отече- } \\
\text { ствомъ посль того какъ } \\
\text { Они оставили Назаретъ } \\
\text { и до переселенія Ихъ въ } \\
\text { Капернаумъ. «И Мати } \\
\text { Іисусова бъ ту.» Мать } \\
\text { семейства. Какъ много- } \\
\text { значительно это слово! } \\
\text { Іосифъ, глава и есте- } \\
\text { ственный хозяинъ дома } \\
\text { этого святаго семейства, } \\
\text { повидимому отошелъ уже } \\
\text { въ въчный покой: радость } \\
\text { и утшшеніе сльдить за даль- } \\
\text { нъйшимъ развитіемъ се- } \\
\text { мьи, о которой онъ такъ } \\
\text { долго заботился, повиди- } \\
\text { мому, не были ему даны. } \\
\text { Но Она, Мать Іисусоваз } \\
\text { непрестанно слагавшая } \\
\text { въ Своемъ сердцъ всъ } \\
\text { мысли и дъянія Сына въ } \\
\text { эти послъднія } 30 \text { льтъ, } \\
\text { Она соединявшая въ себъ } \\
\text { родительскія чувства обоихъ, } \\
\text { и сдълавшаяся такимъ об- } \\
\text { разомъ средоточіемъ того } \\
\text { круга, въ которомъ Она } \\
\text { вращалась, Она осъняла } \\
\text { своимъ благословенімъ } \\
\text { священное собраніе. } \\
\text { «Званъ же бысть Іисусъ } \\
\text { ионечно, но безъ сомнънія }\end{array}$ & $\begin{array}{l}\text { «Въ этомъ счастли- } \\
\text { вомъ и прекрасномъ } \\
\text { селеніи было брачное тор- } \\
\text { жество». Затъмъ описавъ } \\
\text { самый праздникъ и при- } \\
\text { помнивъ всъ брачные } \\
\text { обряды того времени, } \\
\text { проповъдникъ спраши- } \\
\text { ваетъ: }\end{array}$ & $\begin{array}{l}\text { } \\
\\
\text { Дословньй перевод выцелен- } \\
\text { ного фрагмента: «Иосиф, } \\
\text { настоящий глава и храни- } \\
\text { тель дома, как представляет- } \\
\text { ся, отошел в мир иной. Он, } \\
\text { который с таким интересом } \\
\text { наблюдал бы за развитием } \\
\text { семьи, которую давно обе- } \\
\text { регал, - отсутствовал». } \\
\text { Фраза «Мать Иисусова» } \\
\text { добавлена переводчиком. }\end{array}$ \\
\hline
\end{tabular}

${ }^{3}$ Зеленым ияветом выделены фрагменты текста, добавленные переводчиком. 


\begin{tabular}{|c|c|c|c|}
\hline $\begin{array}{c}\text { Проповедь Стенли } \\
\text { (на англ. языке) }\end{array}$ & $\begin{array}{c}\text { Перевод } \\
\text { К. П. Победоносцева } \\
\text { (Гражданинъ. 1874. } \\
\text { № 3. С. 78-81) }\end{array}$ & $\begin{array}{c}\text { Редакционное } \\
\text { изложение } \\
\text { (Гражданинб. 1874. } \\
\text { № 2. С. 37-39) }\end{array}$ & Комментарии \\
\hline $\begin{array}{l}\text { was Simon, whose surname } \\
\text { was taken from Cana; there } \\
\text { was Nathaniel, the guile- } \\
\text { less Israelite, joining in the } \\
\text { glad event which had then } \\
\text { brought to his native vil- } \\
\text { lage the Master whom he } \\
\text { had just acknowledged. }\end{array}$ & $\begin{array}{l}\text { ть первые върные друзья, } \\
\text { которые окружали Своего } \\
\text { Учителя во всъ важныя } \\
\text { минуты жизни. Тутъ были } \\
\text { и рыбаки Галилейска- } \\
\text { го озера: Андрей, Петръ } \\
\text { и Филиппъ, и возлюблен- } \\
\text { ный ученикъ Христовъ; } \\
\text { тутъ были и Симонъ } \\
\text { прозванный Хананейскій } \\
\text { и Наөанаилъ, «воисти- } \\
\text { ну Израильтянинъ, въ } \\
\text { немъ же льсти нбсть», } \\
\text { который особенно радо- } \\
\text { вался тому что Учитель, } \\
\text { такъ недавно имъ при- } \\
\text { знанный, пришель на } \\
\text { праздникъ въ родное его } \\
\text { селеніе. }\end{array}$ & & $\begin{array}{l}\text { Дословный перевод выде- } \\
\text { ленного фрагмента: «...на } \\
\text { праздник пришел Натани- } \\
\text { эль, честный израильтя- } \\
\text { нин, который затем при- } \\
\text { вел Учителя, только что } \\
\text { им признанного, в свое } \\
\text { родное селение». } \\
\text { Фраза «въ немъ же льсти } \\
\text { нъсть» добавлена перевод- } \\
\text { чком. }\end{array}$ \\
\hline $\begin{array}{l}\text { They had all been gathered } \\
\text { together in the neighbour- } \\
\text { hood - they had been there } \\
\text { with their gracious Lord, } \\
\text { willing to be where He was, } \\
\text { willing to follow Him in } \\
\text { trial and distress, willing to } \\
\text { follow him also in happiness } \\
\text { and joy. }\end{array}$ & $\begin{array}{l}\text { Всъ они были съ Нимъ въ } \\
\text { Галилеъ, и безъ сомнънія } \\
\text { всъ они должны были } \\
\text { провести одинъ или два } \\
\text { дня въ Канъ, }\end{array}$ & & $\begin{array}{l}\text { Фрагмент: «Всь они были } \\
\text { съ Нимъ въ Галилеь, } \\
\text { и безъ сомньнія всь они } \\
\text { должны были провести } \\
\text { одинъ или два дня въ } \\
\text { Канъ» - отсутствует } \\
\text { в оригинальном тексте. } \\
\text { Возможно, он в некото- } \\
\text { рой степени заменяет } \\
\text { собою предьдущее опи- } \\
\text { сание: «They had all been } \\
\text { gathered together in the } \\
\text { nеighbourhood - they } \\
\text { had been there with their } \\
\text { gracious Lord, willing to } \\
\text { bе where Не was, willing } \\
\text { to follow Нim in trial and } \\
\text { distress, willing to follow } \\
\text { him also in happiness and } \\
\text { joу» (Дословный перевод } \\
\text { фрагмента: «Все они со- } \\
\text { брались вместе в окрест- } \\
\text { ностях - они были там } \\
\text { с их милосердным Госпо- } \\
\text { дом, желая быть там, где } \\
\text { Он был, сопровождать } \\
\text { его в испытаниях и горе, } \\
\text { а также в счастье и ра- } \\
\text { дости»). }\end{array}$ \\
\hline
\end{tabular}




\begin{tabular}{|c|c|c|c|}
\hline $\begin{array}{c}\text { Проповедь Стенли } \\
\text { (на англ. языке) }\end{array}$ & $\begin{array}{c}\text { Перевод } \\
\text { К. П. Победоносцева } \\
(\text { Гражданинъ. } 1874 . \\
\text { № 3. С. 78-81) }\end{array}$ & $\begin{array}{c}\text { Редакционное } \\
\text { изложение } \\
\text { (Гражданинъ. 1874. } \\
\text { № 2. С. 37-39) }\end{array}$ & Комментарии \\
\hline $\begin{array}{l}\text { One, two days would have } \\
\text { to pass, and "on the third } \\
\text { day" the marriage was to } \\
\text { be. We can figure to our- } \\
\text { selves all the preparations } \\
\text { of those two days, from the } \\
\text { many allusions to such ca- } \\
\text { ses in the Bible. The bride- } \\
\text { groom goes forth to meet } \\
\text { the bride. The young mai- } \\
\text { dens that have known her } \\
\text { are there to greet her, and to } \\
\text { welcome her as she comes } \\
\text { and goes (Matt. XXV. 1. 10). } \\
\text { The lamps and torches flare } \\
\text { along the streets. The wed- } \\
\text { ding garments, bright and } \\
\text { gay, are prepared for the wed- } \\
\text { ding guests (Matt. XXII. 11. } \\
\text { Canticles III. 11). }\end{array}$ & $\begin{array}{l}\text { и уже на третій день на- } \\
\text { значенъ былъ бракъ. Мы } \\
\text { можемъ себъ представить } \\
\text { праздничныя приготов- } \\
\text { ленія въ эти дни, если } \\
\text { вспомнимъ какъ описа- } \\
\text { ны подобныя же торже- } \\
\text { ства въ Ветхомъ Завътъ: } \\
\text { женихъ выходитъ на } \\
\text { встръчу невьстъ, моло- } \\
\text { дыя дъвушки, знавшія ее } \\
\text { прежде, привътствуютъ } \\
\text { ее предлагая свои дары; } \\
\text { фонари и факелы горятъ } \\
\text { вдоль улицъ; свътлые } \\
\text { и радостные свадебные } \\
\text { наряды готовы для сва- } \\
\text { дебныхъ гостей. } \\
\end{array}$ & & $\begin{array}{l}\text { В переводе Победоносиева: } \\
\text { «Bible» - «Ветхій Завьтъ». } \\
\text { Вьıеленная фраза дослов- } \\
\text { но: «радушно приветствуя } \\
\text { еe, пока она шла». } \\
\text { Слово «bright» дословно: } \\
\text { «яркий». }\end{array}$ \\
\hline $\begin{array}{l}\text { The wreaths or crowns, as } \\
\text { still throughout the East, as } \\
\text { in the days of Solomon, and } \\
\text { which even gave the Hebrew } \\
\text { name for the bride - were } \\
\text { ready for the bridal pair. The } \\
\text { brothers are there to bless } \\
\text { their departing sister, as in } \\
\text { the days of Rebekah. The } \\
\text { ancient patriarchal benedic- } \\
\text { tion of the House of Judah is } \\
\text { pronounced upon them - } \\
\text { "The Lord make the wo- } \\
\text { man which is come into thy } \\
\text { house like Rachel, which } \\
\text { did build the house of Isra- } \\
\text { el; and do thou worthily in } \\
\text { Ephratah, and be famous in } \\
\text { Bethlehem" (Gen. XXIV. } 60 \text {. } \\
\text { Ruth. IV. 11). Then came the } \\
\text { marriage feast. Then came } \\
\text { the universal gladness of the } \\
\text { neighbours, far and near. } \\
\text { They rejoiced with the joy } \\
\text { which all must feel in seeing } \\
\text { the joy of others, in the hope } \\
\text { of coming happiness. }\end{array}$ & $\begin{array}{r}\text { Вънки или вънщы - какъ } \\
\text { и теперь водится по всему } \\
\text { Востоку, и употребленіе } \\
\text { ихъ мы находимъ уже } \\
\text { во времена Соломона } \\
\text { (Пъснь Пъсней, III, 11) - } \\
\text { вънцы отъ которыхъ про- } \\
\text { изошло по еврейски слово } \\
\text { «невъста», были приго- } \\
\text { товлены для обручаемыхъ. } \\
\text { Братья собрались что- } \\
\text { бы благословить покидаю- } \\
\text { щую ихъ сестру, какъ это } \\
\text { было во времена Ревекки. } \\
\text { Древнее патріархальное } \\
\text { благословеніе дома Из- } \\
\text { раилева было произнесе- } \\
\text { но надъ молодыми (Руөь, } \\
\text { ІV, 11). «Да дастъ Господь } \\
\text { женъ твоей, входящей въ } \\
\text { домъ твой якоже Рахили } \\
\text { и яко Ліи, яже создаша } \\
\text { объ домъ Израилевъ и со- } \\
\text { твориша силу въ Ефрать } \\
\text { и будеть имя въ Виөлеемъ.» } \\
\text { За симъ посльдовалъ брач- } \\
\text { ный пиръ, общее увеселеніе } \\
\text { всъхъ сосьдей, близкихъ } \\
\text { и далекихъ; радовались } \\
\text { они тою радостію, кото- } \\
\text { рую каждый долженъ чув- } \\
\text { ствовать при видъ счастія } \\
\text { другихъ, въ надеждъ на } \\
\text { свътлую будущность. }\end{array}$ & & $\begin{array}{l}\text { Ссылка «(Пьснь Пьсней, } \\
\text { III, 11)» добавлена авто- } \\
\text { ром перевода. }\end{array}$ \\
\hline
\end{tabular}




\begin{tabular}{|c|c|c|c|}
\hline $\begin{array}{c}\text { Проповедь Стенли } \\
\text { (на англ. языке) }\end{array}$ & $\begin{array}{c}\text { Перевод } \\
\text { К. П. Победоносцева } \\
\text { (Гражданинб. 1874. } \\
\text { № 3. С. 78-81) }\end{array}$ & $\begin{array}{c}\text { Редакционное } \\
\text { изложение } \\
\text { (Гражданинъ. 1874. } \\
\text { № 2. С. 37-39) }\end{array}$ & Комментарии \\
\hline $\begin{array}{l}\text { Outside the chamber were } \\
\text { the vast stone jars filled } \\
\text { with the pure water from } \\
\text { the village well. For guest } \\
\text { after guest was poured out } \\
\text { the water to wash their } \\
\text { hands before they sat down } \\
\text { to the feast, "after the man- } \\
\text { ner of the purifying" of } \\
\text { all Eastern nations, and as } \\
\text { they entered, thus cleansed } \\
\text { and cooled from the dust } \\
\text { and heat of the day, they } \\
\text { found all prepared within. } \\
\text { There was the bridegroom, } \\
\text { and there was "the ruler of } \\
\text { the feast", the bridegroom's } \\
\text { friend, who dispensed the } \\
\text { hospitalities with ungrud- } \\
\text { ging hand. }\end{array}$ & $\begin{array}{l}\text { При входъ въ горницу } \\
\text { стояли большіе камен- } \\
\text { ные сосуды, наполненные } \\
\text { чистою водою деревен- } \\
\text { скихъ колодцевъ. Для } \\
\text { каждаго гостя наливалась } \\
\text { вода, чтобы онъ могъ вы- } \\
\text { мыть руки передъ тьмъ } \\
\text { какъ състь къ празднич- } \\
\text { ному столу - «лежаща } \\
\text { по очищенію іудейску», } \\
\text { по обычаю очищені } \\
\text { всъхъ восточныхъ пле- } \\
\text { менъ; когда гости, омыв- } \\
\text { шись и освъжившись } \\
\text { отъ пыли и жара дневна- } \\
\text { го, входили въ горницу, } \\
\text { тамъ все уже было гото- } \\
\text { во. Здъсь былъ женихъ, } \\
\text { а также и распорядитель } \\
\text { праздника, другъ жениха, } \\
\text { разсыпавшій щедрою ру- } \\
\text { кою дары гостепріимства. }\end{array}$ & & $\begin{array}{l}\text { Ср. буквальный перевод: } \\
\text { the village well - деревен- } \\
\text { ского колодца } \\
\text { Цитата из Евангелия } \\
\text { от Иоанна: «лежаща по } \\
\text { очищенію Іудейску»- } \\
\text { добавлена автором пере- } \\
\text { вода. }\end{array}$ \\
\hline $\begin{array}{l}\text { And when the wine flowed } \\
\text { faster and freer than ever, } \\
\text { and the spirits of the } \\
\text { guests rose higher and } \\
\text { higher, the ruler of the } \\
\text { feast, in the joyousness of } \\
\text { his heart, called the youth- } \\
\text { ful bridegroom, and said. } \\
\text { "Every man at the begin- } \\
\text { ning doth set forth good } \\
\text { wine, but thou hast kept } \\
\text { the good wine until now." } \\
\text { He knew not whence it was. } \\
\text { He saw only the festivity } \\
\text { of the scene; he made only } \\
\text { his merry jests on the good } \\
\text { flavour which he tasted. But } \\
\text { there were those who saw } \\
\text { beyond the outward show. }\end{array}$ & $\begin{array}{l}\text { И вино лилось все } \\
\text { обильнъе и быстръе, } \\
\text { и веселое настроеніе гостей } \\
\text { усиливалось, но вдругь } \\
\text { оказалось что лучшее } \\
\text { вино подано было толь- } \\
\text { ко напосльдокъ. Рас- } \\
\text { порядитель праздника } \\
\text { не зналь откуда оно: онъ } \\
\text { только видъль вокругъ } \\
\text { себя веселыя, празднич- } \\
\text { ныя лица, и сдълалъ свое } \\
\text { меткое замъчаніе о вкусъ } \\
\text { вина, которое ему дали } \\
\text { отвъдать. Но были другіе } \\
\text { взоры, которые проника- } \\
\text { ли тайну того что видъли: }\end{array}$ & & $\begin{array}{l}\text { Автор перевода транс- } \\
\text { формировал фрагмент, } \\
\text { переведя прямую речь в ав- } \\
\text { торское описание. } \\
\text { Дословный перевод фраг- } \\
\text { мента: «И когда вино стало } \\
\text { литься быстрее и щедрее, } \\
\text { чем когда-либо, а настро- } \\
\text { ение гостей улучшалось, } \\
\text { распорядитель свадьбы } \\
\text { с полным радости сердцем } \\
\text { позвал молодого жениха } \\
\text { и сказал: “Каждый чело- } \\
\text { век вначале выставляет } \\
\text { хорошее вино, а ты его } \\
\text { оставил напоследок”». }\end{array}$ \\
\hline $\begin{array}{l}\text { Those who drew the water } \\
\text { knew at whose bidding } \\
\text { that water had become } \\
\text { wine. She, the blessed } \\
\text { Mother, knew, and he who } \\
\text { records the scene has told } \\
\text { us that "this beginning of } \\
\text { miracles did Jesus in Cana } \\
\text { of Galilee, and manifested } \\
\text { forth His glory, and His dis- } \\
\text { ciples believed on Him." }\end{array}$ & $\begin{array}{l}\text { Пресвятая Матерь } \\
\text { и ученики Его, черпая } \\
\text { воду, знали по какому } \\
\text { вельнію вода претвори- } \\
\text { лась въ вино. Св. Еванге- } \\
\text { листъ, который переда- } \\
\text { етъ намъ всъ подробно- } \\
\text { сти этого событія, гово- } \\
\text { ритъ: «Се сотвори нача- } \\
\text { токъ знаменіемъ Іисусъ въ } \\
\text { Канъ Галилейстъй и яви } \\
\text { славу Свою: и вьроваша } \\
\text { въ Него ученицы Его». }\end{array}$ & & $\begin{array}{l}\text { Дословный перевод выде- } \\
\text { ленного фрагмента: «Те, } \\
\text { кто черпали воду, знали, } \\
\text { по чьему велению та вода } \\
\text { превратилась в вино. Она, } \\
\text { Пресвятая Матерь, знала, } \\
\text { и он, кто описывал эту } \\
\text { сцену, рассказал нам...». }\end{array}$ \\
\hline
\end{tabular}




\begin{tabular}{|c|c|c|c|}
\hline $\begin{array}{c}\text { Проповедь Стенли } \\
\text { (на англ. языке) }\end{array}$ & $\begin{array}{c}\text { Перевод } \\
\text { К. П. Победоносцева } \\
(\text { Гражданинъ. } 1874 . \\
\text { № 3. С. 78-81) }\end{array}$ & $\begin{array}{c}\text { Редакционное } \\
\text { изложение } \\
\text { (Гражданинъ. 1874. } \\
\text { № 2. С. 37-39) }\end{array}$ & Комментарии \\
\hline $\begin{array}{l}\text { Into the inner meaning } \\
\text { of that beautiful and pathe- } \\
\text { tic story let us, with those } \\
\text { disciples, penetrate. Let } \\
\text { us ask what there was in } \\
\text { that manifestation which } \\
\text { will give us instruction at } \\
\text { all times, and especially } \\
\text { at this season. First, let us } \\
\text { observe the general lesson } \\
\text { of this earliest sign of our } \\
\text { Lord's public ministry. It } \\
\text { was an occasion not of grief } \\
\text { and mourning, but of in- } \\
\text { nocent happiness and joy. } \\
\text { Doubtless He was a Man of } \\
\text { Sorrows. Doubtless He is } \\
\text { a peculiar sense the Com- } \\
\text { forter of the comfortless, } \\
\text { the Father of the fatherless, } \\
\text { the Friend of those that } \\
\text { have to part with the joy of } \\
\text { their life. }\end{array}$ & $\begin{array}{l}\text { Вникнемъ же теперь, } \\
\text { подобно ученикамъ Его, } \\
\text { во внутреннее значеніе } \\
\text { этого чуднаго и поражаю- } \\
\text { щаго дъйствія. } \\
\\
\text { Чему учитъ насъ это } \\
\text { первое знаменіе обще- } \\
\text { ственнаго служенія наше- } \\
\text { го Господа? Это былъ слу- } \\
\text { чай не горя или испытанія, } \\
\text { а чистой, невинной } \\
\text { радости. Несомнънно, } \\
\text { Онъ по преимуществу } \\
\text { былъ человъкомъ горя } \\
\text { и страданія, несомнбнно } \\
\text { что Онъ въ особен- } \\
\text { номъ, частномъ смысль } \\
\text { Утьшитель безутьшныхъ, } \\
\text { Отецъ сиротъ и всъхъ } \\
\text { тъхъ, сердце которыхъ съ } \\
\text { счастіемъ незнакомо. }\end{array}$ & $\begin{array}{l}\text { «Чему учитъ насъ это } \\
\text { первое знаменіе обще- } \\
\text { ственнаго служенія наше- } \\
\text { го Господа? Это былъ слу- } \\
\text { чай не горя или испытанія, } \\
\text { a чистой, невинной } \\
\text { радости. Несомнънно, } \\
\text { Онъ по преимуществу } \\
\text { былъ человъкомъ горя } \\
\text { и страданія, несомнънно, } \\
\text { что Онъ въ особен- } \\
\text { номъ, частномъ смысль } \\
\text { Утъшитель безутьшныхъ, } \\
\text { Отецъ сиротъ и всъхъ } \\
\text { тъхъ, сердце которыхъ съ } \\
\text { счастіемъ незнакомо. }\end{array}$ & $\begin{array}{l}\text { В переводе Победоносие- } \\
\text { ва пропущено вылеленное } \\
\text { предложение. Дословный } \\
\text { перевод вылеленного пред- } \\
\text { ложения: «Давайте спро- } \\
\text { сим, что было в том про- } \\
\text { явлении, которое даст нам } \\
\text { наставления на все време- } \\
\text { на и, особенно, в данный } \\
\text { период». } \\
\text { Слова «по преимуществу» } \\
\text { добавлень автором перевода } \\
\text { Фраза «Мап оf Sorrows» } \\
\text { буквально: «человеком стра- } \\
\text { даний». }\end{array}$ \\
\hline $\begin{array}{l}\text { Doubtless in the suffe- } \\
\text { ring of the sick chamber } \\
\text { and by the bed of death, } \\
\text { and beside the open grave, } \\
\text { we feel and we need His } \\
\text { presence more than any- } \\
\text { where else. }\end{array}$ & & & $\begin{array}{l}\text { У Победоносиева перевод } \\
\text { данного фрагмента от- } \\
\text { сутствует. } \\
\text { Дословный перевод фраг- } \\
\text { мента: «Несомненно, стра- } \\
\text { дая от болезней, находясь } \\
\text { на смертном одре, и на } \\
\text { краю открытой могилы, } \\
\text { мы чувствуем Его прису- } \\
\text { ствие и нуждаемся в нем } \\
\text { больше, чем где-либо еще». }\end{array}$ \\
\hline $\begin{array}{l}\text { Doubtless over all His } \\
\text { brightest relaxations, as } \\
\text { over His homeliest occu- } \\
\text { pations, there was cast "the } \\
\text { shadow of the Cross"; and } \\
\text { by that Cross, by the seri- } \\
\text { ous sense of what life is, and } \\
\text { what death is we also, in our } \\
\text { happiest, as well as in our } \\
\text { gloomiest, hours, are sup- } \\
\text { ported. But as in our com- } \\
\text { mon life there are moments } \\
\text { of unmixed rejoicing, so it } \\
\text { was with Him. He teaches } \\
\text { us "to weep with those that } \\
\text { weep"; but He teaches us } \\
\text { no less to rejoice with those }\end{array}$ & $\begin{array}{l}\text { Несомнънно и то что } \\
\text { тънь креста осъняла какъ } \\
\text { самые высокіе, такъ и са- } \\
\text { мые простые Его подви- } \\
\text { ги и дъянія. И этотъ-то } \\
\text { крестъ и глубокая мысль } \\
\text { о значеніи жизни и смер- } \\
\text { ти и намъ приноситъ } \\
\text { утъшеніе и опору какъ въ } \\
\text { счастливъйшіе, такъ и въ } \\
\text { самые тяжелые и печаль- } \\
\text { ные дни нашей жизни. } \\
\text { Но подобно тому, какъ въ } \\
\text { нашей обыденной жизни } \\
\text { встръчаются мгновенія } \\
\text { ничъмъ неомрачаема- } \\
\text { го, полнаго счастія, такъ }\end{array}$ & $\begin{array}{l}\text { Несомнънно и то что } \\
\text { тънь креста осъняла какъ } \\
\text { самые высокіе, такъ и са- } \\
\text { мые простые Его под- } \\
\text { виги и дъянія. И этотъ- } \\
\text { то крестъ и глубокая } \\
\text { мысль о значеніи жизни } \\
\text { и смерти и намъ прино- } \\
\text { ситъ утьшеніе и опору } \\
\text { какъ въ счастливъйшіе, } \\
\text { такъ и въ самые тяжелые } \\
\text { и печальные дни нашей } \\
\text { жизни. Но подобно тому, } \\
\text { какъ въ нашей обыден- } \\
\text { ной жизни встръчаются } \\
\text { мгновенія ничъмъ не- } \\
\text { омрачаемаго, полнаго }\end{array}$ & $\begin{array}{l}\text { Вьцеленная фраза бук- } \\
\text { вально: «Он учит нас пла- } \\
\text { кать с плачущими...». }\end{array}$ \\
\hline
\end{tabular}




\begin{tabular}{|c|c|c|c|}
\hline $\begin{array}{c}\text { Проповедь Стенли } \\
\text { (на англ. языке) }\end{array}$ & $\begin{array}{c}\text { Перевод } \\
\text { К. П. Победоносцева } \\
\text { (Гражданинъ. 1874. } \\
\text { № 3. С. 78-81) }\end{array}$ & $\begin{array}{c}\text { Редакционное } \\
\text { изложение } \\
\text { (Гражданинъ. 1874. } \\
\text { № 2. С. 37-39) }\end{array}$ & Комментарии \\
\hline $\begin{array}{l}\text { that rejoice. "His rod and } \\
\text { his staff are with us through } \\
\text { the valley of the shadow of } \\
\text { death"; but it is He also who } \\
\text { has "spread a table for us" in } \\
\text { this world's wilderness, and } \\
\text { "made our cup run over", } \\
\text { and "followed us with good- } \\
\text { ness and mercy all the days } \\
\text { of our life" (Psalm. XXIII. } \\
4,5,6) \text {. }\end{array}$ & $\begin{array}{l}\text { было и съ Нимъ. Осо- } \\
\text { бенная, высокая задача } \\
\text { христіанства призыва- } \\
\text { етъ насъ не только пла- } \\
\text { кать съ плачущими, но } \\
\text { и радоваться съ радую- } \\
\text { щимися. Его жезлъ и па- } \\
\text { лица ведутъ насъ черезъ } \\
\text { горькую долину смерти, } \\
\text { но не Онъ-ли тоже при- } \\
\text { готовилъ намъ трапезу } \\
\text { среди земной пустыни, } \\
\text { не Онъ-ли наполняетъ } \\
\text { черезъ край наши чаши, } \\
\text { не Онъ-ли не оставляетъ } \\
\text { насъ своими милостями } \\
\text { и щедротами во всъ дни } \\
\text { нашей жизни. }\end{array}$ & $\begin{array}{l}\text { счастія, такъ было и съ } \\
\text { Нимъ. Особенная, высо- } \\
\text { кая задача христіанства } \\
\text { призываетъ насъ не толь- } \\
\text { ко плакать съ плачущими, } \\
\text { но и радоваться съ раду- } \\
\text { ющимися. Его жезлъ и па- } \\
\text { лица ведутъ насъ черезъ } \\
\text { горькую долину смерти, } \\
\text { но не Онъ-ли тоже при- } \\
\text { готовилъ намъ трапезу } \\
\text { среди земной пустыни, } \\
\text { не Онъ-ли наполняетъ } \\
\text { черезъ край наши чаши, } \\
\text { не Онъ-ли не оставляетъ } \\
\text { насъ своими милостями } \\
\text { и щедротами во всъ дни } \\
\text { нашей жизни. }\end{array}$ & \\
\hline $\begin{array}{l}\text { At the house of Levi the } \\
\text { Publican, in the house of } \\
\text { Simon the Pharisee, in the } \\
\text { house of Martha and Mary, } \\
\text { in the house of Zacchseus, } \\
\text { He was to be found feasting } \\
\text { and rejoicing, no less than } \\
\text { in sympathy with grief in } \\
\text { the sick chamber of the } \\
\text { little daughter of Jairus, or } \\
\text { with the weeping widow of } \\
\text { Nain, or before the grave of } \\
\text { Lazarus. }\end{array}$ & & & $\begin{array}{l}\text { У Победоносиева перевод } \\
\text { данного фрагмента отсут- } \\
\text { ствует. } \\
\text { Дословный перевод фраг- } \\
\text { мента: «В доме Левия Мы- } \\
\text { таря, Симеона Фарисея, } \\
\text { Марты и Марии, Закхея его } \\
\text { можно было видеть празд- } \\
\text { нующим и радующимся } \\
\text { так же, как в доме Иаира } \\
\text { сострадающим его горю } \\
\text { об умершей маленькой до- } \\
\text { чери, или в городе Наине } \\
\text { оплакивающим сына вдо- } \\
\text { вы, или у могилы Лазаря». }\end{array}$ \\
\hline $\begin{array}{l}\text { The disciples of John } \\
\text { and of the Pharisees fasted } \\
\text { oft, but He fasted not. He } \\
\text { was the Bridegroom of } \\
\text { them all. His life on earth, } \\
\text { even in the midst of sor- } \\
\text { row, was a perpetual mar- } \\
\text { riage feast, and "the child- } \\
\text { ren of the Bridechamber } \\
\text { could not mourn as long as } \\
\text { the Bridegroom was with } \\
\text { them" (Mark. II. 18-20). }\end{array}$ & $\begin{array}{l}\text { Ученики Іоанна Кре- } \\
\text { стителя и фарисейскіе } \\
\text { постились часто, Онъ же } \\
\text { не постился; Онъ быль } \\
\text { какъ бы счастливый } \\
\text { женихъ всъхъ окружа- } \\
\text { ющихъ Его. Его земная } \\
\text { жизнь даже среди горя } \\
\text { и страданій походила на } \\
\text { безпрерывный брачный } \\
\text { пиръ. Дъти брачнаго чер- } \\
\text { тога не могли грустить } \\
\text { и плакать пока женихъ } \\
\text { быль съ ними. }\end{array}$ & $\begin{array}{l}\text { Ученики Іоанна Кре- } \\
\text { стителя и фарисейскіе по- } \\
\text { стились часто, Онъ же не } \\
\text { постился; Онъ былъ какъ } \\
\text { бы счастливый женихъ } \\
\text { всъхъ окружающихъ Его. } \\
\text { Его земная жизнь даже } \\
\text { среди горя и страданій } \\
\text { походила на безпрерыв- } \\
\text { ный брачный пиръ. Дьти } \\
\text { брачнаго чертога не могли } \\
\text { грустить и плакать пока } \\
\text { женихъ былъ съ ними. }\end{array}$ & $\begin{array}{l}\text { Выделенная фраза бук- } \\
\text { вально: «Он был женихом } \\
\text { их всех». }\end{array}$ \\
\hline
\end{tabular}




\begin{tabular}{|c|c|c|c|}
\hline $\begin{array}{c}\text { Проповедь Стенли } \\
\text { (на англ. языке) }\end{array}$ & $\begin{array}{c}\text { Перевод } \\
\text { К. П. Победоносцева } \\
\text { (Гражданинъ. 1874. } \\
\text { № 3. С. 78-81) }\end{array}$ & $\begin{array}{c}\text { Редакционное } \\
\text { изложение } \\
\text { (Гражданинъ. 1874. } \\
\text { № 2. С. 37-39) }\end{array}$ & Комментарии \\
\hline $\begin{array}{l}\text { To them, as to us all in } \\
\text { the time of this mortal life, } \\
\text { the time of sorrow would } \\
\text { come; but not yet. These } \\
\text { feasts would still continue. } \\
\text { He would still enjoy their } \\
\text { pleasantness. }\end{array}$ & & & $\begin{array}{l}\text { У Победоносиева перевод } \\
\text { данного фрагмента от- } \\
\text { сутствует. } \\
\text { Дословный перевод фраг- } \\
\text { мента: «Для них, как } \\
\text { для нас в течение нашей } \\
\text { смертной жизни, время } \\
\text { страданий еще настанет. } \\
\text { А пока продолжаются } \\
\text { празднества. Он все еще } \\
\text { наслаждается их удоволь- } \\
\text { ствиями». }\end{array}$ \\
\hline $\begin{array}{l}\text { He would still from them } \\
\text { derive the choicest illus- } \\
\text { trations of His discour- } \\
\text { ses; the parable of the mar- } \\
\text { riage supper, of the wedding } \\
\text { garment, of the crowded } \\
\text { tables. Nay even the most } \\
\text { solemn ordinance of His } \\
\text { Church, founded on the } \\
\text { very eve of His Passion, was } \\
\text { the memorial of a feast, of } \\
\text { an evening supper, of a par- } \\
\text { ting meal, which having } \\
\text { loved His own even to the } \\
\text { end He had desired to share } \\
\text { with them to the last. Those } \\
\text { few particles of sacred bread } \\
\text { that we eat are, as it were, } \\
\text { the crumbs of the bread that } \\
\text { "strengthened man's life", } \\
\text { from the golden cornfields } \\
\text { of Palestine. }\end{array}$ & 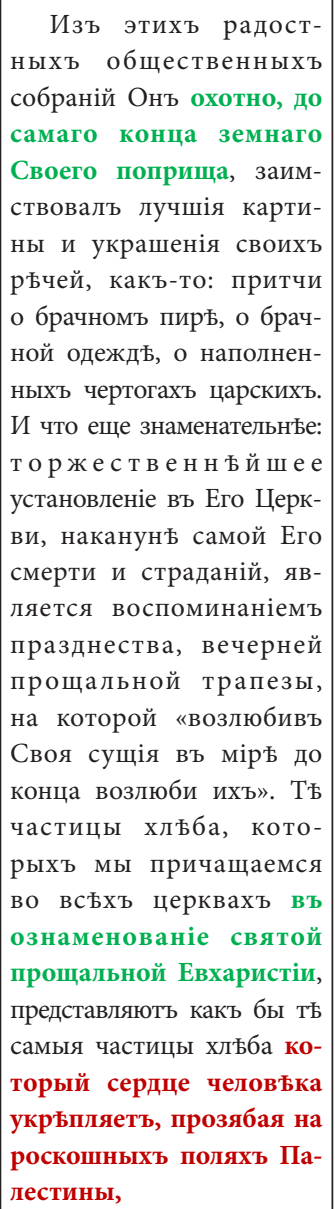 & $\begin{array}{r}\text { Изъ этихъ радост- } \\
\text { ныхъ общественныхъ } \\
\text { собраній Онъ охотно, } \\
\text { до самаго конца земнаго } \\
\text { Своего поприща, заим- } \\
\text { ствовалъ лучшія карти- } \\
\text { ны и украшенія своихъ } \\
\text { ръчей, какъ-то: притчи } \\
\text { о брачномъ пиръ, о брач- } \\
\text { ной одеждъ, о наполнен- } \\
\text { ныхъ чертогахъ царскихъ. } \\
\text { И что еще знаменательнъе: } \\
\text { т о же с т е н в й ше е } \\
\text { установленіе въ Его Церк- } \\
\text { ви, наканунъ самой Его } \\
\text { смерти и страданій, яв- } \\
\text { ляется воспоминаніемъ } \\
\text { празднества, вечерней } \\
\text { прощальной трапезы, на } \\
\text { которой «возлюбивъ Своя } \\
\text { сущія въ міръ до конца } \\
\text { возлюби ихъ». }\end{array}$ & $\begin{array}{l}\text { Дословный перевод выље- } \\
\text { ленного фрагмента: «...ко- } \\
\text { торый укрепляет человече- } \\
\text { скую жизнь, с золотых куку- } \\
\text { рузных полей Палестины» } \\
\text { Слова «въ ознаменованіе } \\
\text { святой прощальной Евха- } \\
\text { ристіи» добавлены авто- } \\
\text { ром перевода. }\end{array}$ \\
\hline
\end{tabular}




\begin{tabular}{|c|c|c|c|}
\hline $\begin{array}{c}\text { Проповедь Стенли } \\
\text { (на англ. языке) }\end{array}$ & $\begin{array}{c}\text { Перевод } \\
\text { К. П. Победоноцева } \\
\text { (Гражданинб. 1874. } \\
\text { № 3. С. 78-81) }\end{array}$ & $\begin{array}{c}\text { Редакционное } \\
\text { изложение } \\
\text { (Гражданинб. 1874. } \\
\text { № 2. С. 37-39) }\end{array}$ & Комментарии \\
\hline $\begin{array}{l}\text { Those few drops of wine } \\
\text { that we drink are but the } \\
\text { drops of the overflowing } \\
\text { cups which made glad the } \\
\text { heart of man in the Upper } \\
\text { Chamber of Jerusalem and } \\
\text { at the Wedding Feast of } \\
\text { Cana. That gathering before } \\
\text { or around the Sacred Table } \\
\text { is the continuance of the } \\
\text { tender meetings and part- } \\
\text { ings with dear friends, with } \\
\text { beloved children, of which } \\
\text { the Last Supper was the } \\
\text { great example. }\end{array}$ & $\begin{array}{l}\text { а капля вина, которое мы } \\
\text { пьемъ изъ священна- } \\
\text { го потира, напоминаетъ } \\
\text { то самое вино «веселя- } \\
\text { щее сердце человъка», } \\
\text { которымъ была пере- } \\
\text { полнена чаша верхней } \\
\text { горницы іерусалимской } \\
\text { и то вино, которое ли- } \\
\text { лось на брачномъ пирь } \\
\text { въ Канъ Галилейской; } \\
\text { наше соединеніе вокругъ } \\
\text { священной трапезы есть } \\
\text { продолженіе нъжнаго } \\
\text { соединенія и прощанія съ } \\
\text { дорогими друзьями, бра- } \\
\text { тьями, сестрами и люби- } \\
\text { мыми дътьми, прообра- } \\
\text { зомъ которыхъ служитъ } \\
\text { послъдняя вечерняя тра- } \\
\text { пеза нашего Господа. }\end{array}$ & & $\begin{array}{l}\text { Слова «изъ священнаго } \\
\text { потира» добавлены авто- } \\
\text { ром перевода. } \\
\\
\text { Слова «братьями, сестра- } \\
\text { ми» добавлены автором } \\
\text { перевода. }\end{array}$ \\
\hline $\begin{array}{l}\text { Forget not His hardships - } \\
\text { forget not His poverty - } \\
\text { forget not His bitter Cross } \\
\text { and Passion; but in thank- } \\
\text { fulness to Him, and in } \\
\text { mercy to ourselves, let us } \\
\text { remember no less the joy- } \\
\text { ous days and hours of His } \\
\text { common life. Remember } \\
\text { that if He was acquainted } \\
\text { with our griefs, He was also } \\
\text { acquainted with our joys; if } \\
\text { He was despised and reject- } \\
\text { ed of men, smitten of God, } \\
\text { and afflicted, He was also } \\
\text { beloved of God and man, } \\
\text { "fairer than the sons of men, } \\
\text { anointed with the oil of } \\
\text { gladness above His fellows." }\end{array}$ & & & $\begin{array}{l}\text { У Победоносиева перевод } \\
\text { данного фрагмента от- } \\
\text { сутствует. } \\
\text { Дословный перевод фраг- } \\
\text { мента: «Не забудем Его } \\
\text { лишения, не забудем Его } \\
\text { бедность, не забудем Его } \\
\text { горький Крест и Страда- } \\
\text { ния; но в благодарность } \\
\text { Ему и из сострадания } \\
\text { к нам самим, давайте так- } \\
\text { же помнить счастливые } \\
\text { дни и часы Его обычной } \\
\text { жизни. Помните, что если } \\
\text { Он познал наши горести, } \\
\text { он познал и наши радо- } \\
\text { сти. Если Он был прези- } \\
\text { раем и отвержен людьми, } \\
\text { поверженный и сокру- } \\
\text { шенный Богом, то он так- } \\
\text { же был любим Богом и че- } \\
\text { ловеком, «помазанный } \\
\text { елеем радости более, чем } \\
\text { соучастники Его». }\end{array}$ \\
\hline
\end{tabular}




\begin{tabular}{|c|c|c|c|}
\hline $\begin{array}{c}\text { Проповедь Стенли } \\
\text { (на англ. языке) }\end{array}$ & $\begin{array}{c}\text { Перевод } \\
\text { К. П. Победоносцева } \\
\text { (Гражданинъ. 1874. } \\
\text { № 3. С. 78-81) }\end{array}$ & $\begin{array}{c}\text { Редакционное } \\
\text { изложение } \\
\text { (Гражданинъ. 1874. } \\
\text { № 2. С. 37-39) }\end{array}$ & Комментарии \\
\hline $\begin{array}{l}\text { The Feast of Cana, which } \\
\text { represents to us one whole } \\
\text { side of our Lord's life too } \\
\text { often overlooked, is in- } \\
\text { deed a proof of His Divine } \\
\text { mission, because it brings } \\
\text { out forcibly that peculia- } \\
\text { rity of social existence by } \\
\text { which His course was dis- } \\
\text { tinguished from the Found- } \\
\text { ers of all other Creeds. It is } \\
\text { a lesson needed for all of us, } \\
\text { (religious as well as irreli- } \\
\text { gious, irreligious as well as } \\
\text { religious), because it tells us } \\
\text { that not only a saintly, not } \\
\text { only an angelic, but a Di- } \\
\text { vine life may be lived amid } \\
\text { the enjoyments and the } \\
\text { temptations of the world; } \\
\text { that through our pleasures } \\
\text { no less than through our } \\
\text { sorrows our characters } \\
\text { may be strengthened and } \\
\text { our tempers sweetened, } \\
\text { and our minds opened and } \\
\text { our thoughts elevated. It } \\
\text { teaches us that the most } \\
\text { religious life is that of those } \\
\text { who, bearing the burdens of } \\
\text { public duty and ministering } \\
\text { to others' happiness, and } \\
\text { enjoying all that there, is of } \\
\text { good and beautiful in the } \\
\text { world, are yet able to hold } \\
\text { their own against its evil - } \\
\text { are determined to turn aside } \\
\text { from every act of foolish } \\
\text { or wrong indulgence, with } \\
\text { the same firm and just dis- } \\
\text { pleasure that we know we } \\
\text { should have seen in Jesus } \\
\text { Christ. }\end{array}$ & 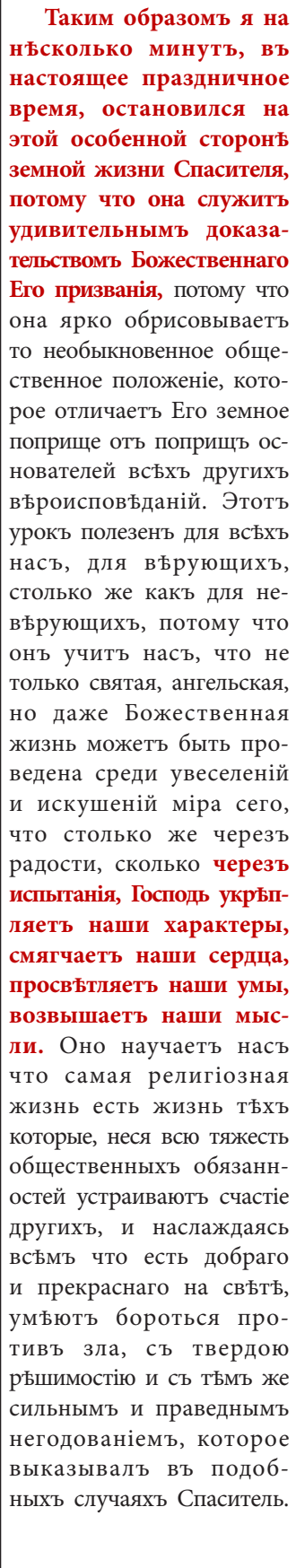 & 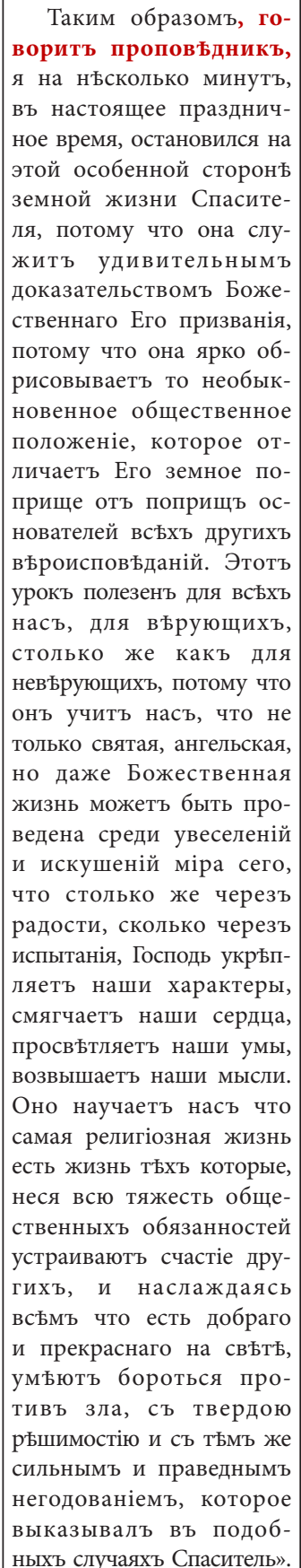 & $\begin{array}{l}\text { Дословный перевод выље- } \\
\text { ленного фрагмента: «Пир } \\
\text { в Кане, который представ- } \\
\text { ляет нам целую сторону } \\
\text { жизни нашего Господа, на } \\
\text { которую часто не обра- } \\
\text { щают внимания, на самом } \\
\text { деле является доказатель- } \\
\text { свтом его Божественной } \\
\text { миссии». }\end{array}$ \\
\hline
\end{tabular}




\begin{tabular}{|c|c|c|c|}
\hline $\begin{array}{c}\text { Проповедь Стенли } \\
\text { (на англ. языке) }\end{array}$ & $\begin{array}{c}\text { Перевод } \\
\text { К. П. Победоноцева } \\
\text { (Гражданинъ. 1874. } \\
\text { № 3. С. 78-81) }\end{array}$ & $\begin{array}{c}\text { Редакционное } \\
\text { изложение } \\
\text { (Гражданинъ. 1874. } \\
\text { № 2. С. 37-39) }\end{array}$ & Комментарии \\
\hline $\begin{array}{l}\text { And this brings us to } \\
\text { consider the yet further } \\
\text { lesson, which this story } \\
\text { teaches us. The innocence } \\
\text { of enjoyment is not the } \\
\text { whole lesson taught us by } \\
\text { the feast at Cana. It was } \\
\text { not only a Feast - it was } \\
\text { a Marriage Feast. It was not } \\
\text { only that our Saviour took } \\
\text { occasion to make His first } \\
\text { manifestation of Himself at } \\
\text { a festive banquet, but that } \\
\text { «He beautified and adorned } \\
\text { with His presence, and by } \\
\text { the first miracle that He } \\
\text { wrought", the holy estate of } \\
\text { marriage. He enlivened, He } \\
\text { cheered, He encouraged } \\
\text { all that is bound up in that } \\
\text { blessed word. And what } \\
\text { He did then He did, as far } \\
\text { as it was possible, through- } \\
\text { out His course. He indeed } \\
\text { Himself had not, could not } \\
\text { have, a home of His own. } \\
\text { But all short of this He had. } \\
\text { He had His mother, His } \\
\text { brothers and His sisters. He } \\
\text { had his own dear friends - } \\
\text { John, the beloved disciple; } \\
\text { Lazarus, whom he loved } \\
\text { with a brother's love; Mar- } \\
\text { mond James and Jude, and Si- } \\
\text { tha and Mary, whose home } \\
\text { was His home. He had with } \\
\text { him His apostles - all of } \\
\text { them, (save one doubtful } \\
\text { exception), if we may trust } \\
\text { monistian tradition, mar- }\end{array}$ & $\begin{array}{l}\text { ІІ. Эти соображенія } \\
\text { приводятъ меня ко вто- } \\
\text { рой сторонъ вопроса: не- } \\
\text { винность христіанскаго } \\
\text { веселья не есть един- } \\
\text { ственное заключеніе, ко- } \\
\text { торое мы можемъ извлечь } \\
\text { изъ сказанья о бракъ въ } \\
\text { Канъ Галилейской: это } \\
\text { былъ не простой пиръ, } \\
\text { а брачный пиръ. Дьло за- } \\
\text { ключалось не только въ } \\
\text { томъ что нашъ Спаситель } \\
\text { въ первый разъ явиль } \\
\text { Себя на праздничномъ } \\
\text { пиръ, но и въ томъ что } \\
\text { Онъ украсилъ и Своимъ } \\
\text { присутствіемъ, а равно } \\
\text { и первымъ сотвореннымъ } \\
\text { Имъ чудомъ святое до- } \\
\text { стоинство брака. И надо } \\
\text { замътить что этотъ слу- } \\
\text { чай быль только однимъ } \\
\text { изъ многихъ, въ которые } \\
\text { Онъ ободряль и освя- } \\
\text { щалъ такимъ образомъ } \\
\text { все что заключаетъ въ } \\
\text { себъ это священное } \\
\text { понятіе. у Него Самого не } \\
\text { было и не могло быть сво- } \\
\text { его домашняго очага, но } \\
\text { кромъ собственнаго дома } \\
\text { все у Него было, и все } \\
\text { во всей полнотъ: у Него } \\
\text { была мать, братья, сестры, } \\
\text { дорогіе друзья, Іоаннъ, } \\
\text { возлюбленный Его уче- } \\
\text { никъ, Лазарь, котораго } \\
\text { Онъ любилъ какъ бра- } \\
\text { та, Марөа и Марія, подъ } \\
\text { кровлею коихъ Онъ всегда } \\
\text { находилъ Себъ убъжище. } \\
\text { У Него были Его ученики } \\
\text { всъ (съ однимъ сомни- } \\
\text { тельнымъ исключеніемъ), } \\
\text { какъ гласитъ священное } \\
\text { преданіе, люди жена- } \\
\text { тые: Петръ, несомнънно } \\
\text { и Іаковъ, Іуда и Симонъ } \\
\text { и Іосифъ }\end{array}$ & $\begin{array}{l}\text { Затъмъ проповъдникъ } \\
\text { переходитъ ко второй } \\
\text { главной мысли своего } \\
\text { слова: онъ напоминаетъ } \\
\text { что пиръ Каны Галилей- } \\
\text { ской былъ не простой, } \\
\text { а брачный пиръ, и что } \\
\text { первое чудо Имъ сотво- } \\
\text { ренное было на брач- } \\
\text { номъ пиръ. }\end{array}$ & 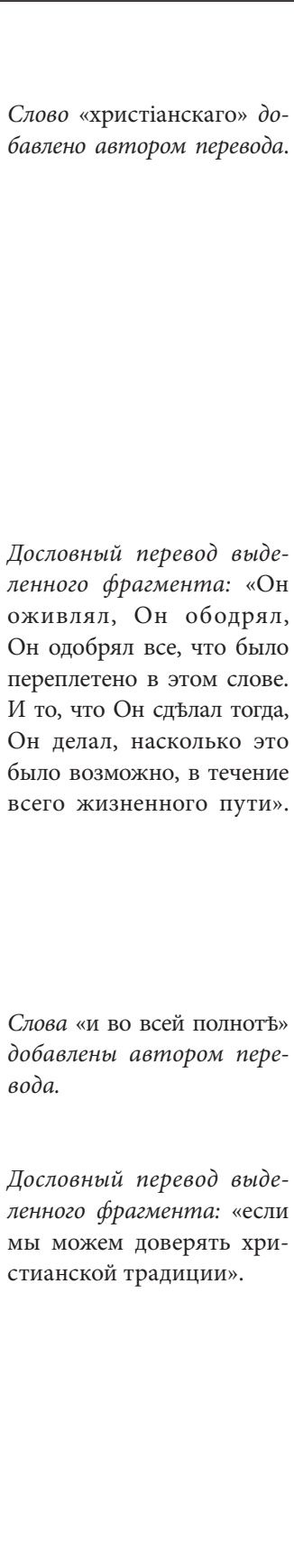 \\
\hline
\end{tabular}




\begin{tabular}{|c|c|c|c|}
\hline $\begin{array}{c}\text { Проповедь Стенли } \\
\text { (на англ. языке) }\end{array}$ & $\begin{array}{c}\text { Перевод } \\
\text { К. П. Победоносцева } \\
\text { (Гражданинб. } 1874 . \\
\text { № 3. С. 78-81) }\end{array}$ & $\begin{array}{c}\text { Редакционное } \\
\text { изложение } \\
\text { (Гражданинъ. 1874. } \\
\text { № 2. С. 37-39) }\end{array}$ & Комментарии \\
\hline $\begin{array}{l}\text { And in the children that } \\
\text { gathered round Him He } \\
\text { took an unceasing delight } \\
\text { and interest. He command- } \\
\text { ed the playful, unconscious } \\
\text { little ones to be brought to } \\
\text { Him. "He blamed and was } \\
\text { much displeased" at those } \\
\text { who would have kept them } \\
\text { from Him. He exhorted all } \\
\text { men to follow the innocen- } \\
\text { cy which shone out of their } \\
\text { simple faces, out of their } \\
\text { sparkling eyes. By His out- } \\
\text { ward gesture and deed He } \\
\text { declared His goodwill to- } \\
\text { wards them. He embraced } \\
\text { them in His arms, He laid } \\
\text { His hands on their little } \\
\text { heads, He blessed them with } \\
\text { the fulness of His blessing. } \\
\text { He bade us see in their pure } \\
\text { transparent natures a reflec- } \\
\text { tion of Heaven, a foretaste of } \\
\text { Paradise. From these words } \\
\text { and acts, and from the spi- } \\
\text { rit which breathes through } \\
\text { them, Marriage and Home } \\
\text { received a new sanction and } \\
\text { a new position in the history } \\
\text { of mankind. }\end{array}$ & $\begin{array}{l}\text { А съ какимъ радост- } \\
\text { нымъ участіемъ Онъ об- } \\
\text { ращался съ дътьми соби- } \\
\text { равшимися вокругъ Него. } \\
\text { Онъ повелъвалъ прино- } \\
\text { сить къ Себъ веселыхъ, } \\
\text { невинныхъ малютокъ. } \\
\text { Онъ осуждалъ и даже } \\
\text { укорялъ тъхъ которые } \\
\text { возбраняли имъ при- } \\
\text { ближаться къ Нему. Онъ } \\
\text { увъщевалъ всъхъ людей } \\
\text { обратиться къ той невин- } \\
\text { ности, которая сіяла на } \\
\text { ихъ простыхъ личикахъ } \\
\text { и въ ихъ свътлыхъ взо- } \\
\text { рахъ. Своимъ внъшнимъ } \\
\text { обращеніемъ и Своими } \\
\text { дъйствіями Онъ выказы- } \\
\text { валъ Свое доброе къ нимъ } \\
\text { расположеніе; Онъ обни- } \\
\text { малъ ихъ, Онъ возлагалъ } \\
\text { Свои руки на ихъ головки, } \\
\text { Онъ благословляль ихъ } \\
\text { Своимъ благодатнымъ } \\
\text { благословеніемъ: Онъ на- } \\
\text { учаетъ насъ видъть въ ихъ } \\
\text { чистыхъ, невинныхъ при- } \\
\text { родахъ отраженіе неба, } \\
\text { предчувствіе рая. И отъ } \\
\text { этихъ словъ и дъйствій, } \\
\text { отъ духовнаго ихъ смыс- } \\
\text { ла, учрежденіе брака за- } \\
\text { имствовало новыя осно- } \\
\text { вы, новое освященіе въ } \\
\text { исторіи человъчества. }\end{array}$ & & $\begin{array}{l}\text { Дословный перевод выде- } \\
\text { ленного фрагмента: «брака } \\
\text { и семьи». }\end{array}$ \\
\hline $\begin{array}{l}\text { The institution of Chris- } \\
\text { tian marriage, the blessing } \\
\text { of a Christian home have } \\
\text { been worthy of this first be- } \\
\text { ginning of miracles. They } \\
\text { are the bulwarks of nations } \\
\text { and churches. They are the } \\
\text { salt of the corrupt society of } \\
\text { earth which would dissolve } \\
\text { and perish without them. } \\
\text { They are the solid barriers } \\
\text { against superstition on one } \\
\text { side and unbelief on the } \\
\text { other, they are God's own }\end{array}$ & $\begin{array}{l}\text { Постановленіе хрис- } \\
\text { тіанскаго брака и благос- } \\
\text { ловеніе заключающееся } \\
\text { въ христіанской семьъ } \\
\text { были какъ-бы достойны } \\
\text { того, чтобы Христосъ ос- } \\
\text { вятилъ ихъ первымъ Сво- } \\
\text { имъ чудомъ. Они служатъ } \\
\text { основою народовъ и церк- } \\
\text { вей, они соль развращен- } \\
\text { наго общества, которое } \\
\text { безъ нихъ распалось бы } \\
\text { и уничтожилось! Они слу- } \\
\text { жатъ крьпкими преградами }\end{array}$ & $\begin{array}{l}\text { «Постановленіе хрис- } \\
\text { тіанскаго брака», говоритъ } \\
\text { проповъдникъ, «и благос- } \\
\text { ловеніе заключающееся } \\
\text { въ христіанской семьъ } \\
\text { были какъ-бы достойны } \\
\text { того, чтобы Христосъ ос- } \\
\text { вятилъ ихъ первымъ Сво- } \\
\text { имъ чудомъ. Они служатъ } \\
\text { основою народовъ и церк- } \\
\text { вей, они соль развращен- } \\
\text { наго общества, которое } \\
\text { безъ нихъ распалось бы } \\
\text { и уничтожилось! Они }\end{array}$ & \\
\hline
\end{tabular}




\begin{tabular}{|c|c|c|c|}
\hline $\begin{array}{c}\text { Проповедь Стенли } \\
\text { (на англ. языке) }\end{array}$ & $\begin{array}{c}\text { Перевод } \\
\text { К. П. Победоноцева } \\
\text { (Гражданинъ. 1874. } \\
\text { № 3. С. 78-81) }\end{array}$ & $\begin{array}{c}\text { Редакционное } \\
\text { изложение } \\
\text { (Гражданинъ. 1874. } \\
\text { № 2. С. 37-39) }\end{array}$ & Комментарии \\
\hline $\begin{array}{l}\text { safeguards against the ab- } \\
\text { sorbing tyranny either of } \\
\text { the world or of the church. }\end{array}$ & $\begin{array}{l}\text { противъ суевърія съ од- } \\
\text { ной стороны и безвърія } \\
\text { съ другой, ими Богъ } \\
\text { противодъйствуетъ все- } \\
\text { покоряющему господ- } \\
\text { ству матеріальнаго міра } \\
\text { и его суеты! }\end{array}$ & $\begin{array}{l}\text { служатъ крЂпкими пре- } \\
\text { градами противъ суевЂрія } \\
\text { съ одной стороны и без- } \\
\text { вЂрія съ другой, ими Богъ } \\
\text { противодъйствуетъ все- } \\
\text { покоряющему господству } \\
\text { матеріальнаго міра и его } \\
\text { суеты!» }\end{array}$ & $\begin{array}{l}\text { Дословный перевод выделен- } \\
\text { ного фрагмента: «они - } \\
\text { защита Бога против все- } \\
\text { поглощающего господства } \\
\text { либо мира либо церкви». }\end{array}$ \\
\hline $\begin{array}{l}\text { A happy marriage consider } \\
\text { what this is, what it may be, } \\
\text { wherever it occurs, whether } \\
\text { in high places or in humble. } \\
\text { It is not only the blending } \\
\text { together of two human souls } \\
\text { for the mutual society, com- } \\
\text { fort, and help of each - } \\
\text { not only a constant giving } \\
\text { and taking of the purest } \\
\text { happiness, but also a new } \\
\text { beginning of life, a new } \\
\text { starting-point of useful- } \\
\text { ness. It is the great call, once } \\
\text { for all, to leave the past } \\
\text { with its errors, and faults, } \\
\text { and follies far, far behind } \\
\text { us, and to press forward } \\
\text { with new hopes, and new } \\
\text { courage, and new strength } \\
\text { into the future which lies } \\
\text { before us. }\end{array}$ & $\begin{array}{l}\text { Счастливый бракъ. } \\
\text { Что это значитъ, и ка- } \\
\text { кой долженъ быть этоть } \\
\text { бракъ? Гдъ бы онъ ни со- } \\
\text { вершался, въ высокихъ ли } \\
\text { положеніяхъ жизни, или } \\
\text { въ смиренныхъ, онъ есть } \\
\text { не только сліяніе двухъ } \\
\text { человъческихъ душъ для } \\
\text { взаимнаго общенія и по- } \\
\text { мощи, не только постоян- } \\
\text { ный обмънъ чистьйшаго } \\
\text { счастья, но также новый } \\
\text { источникъ обновленія } \\
\text { и спасенія; да, это есть } \\
\text { какъ бы посльдній вели- } \\
\text { кій призывъ разъ навсег- } \\
\text { да отбросить отъ себя } \\
\text { прошедшее со всьми его } \\
\text { заблужденіями, ошиб- } \\
\text { ками и безуміемъ, от- } \\
\text { бросить далеко, далеко, } \\
\text { назадъ, чтобы съ новы- } \\
\text { ми надеждами, новымъ } \\
\text { мужествомъ и новою } \\
\text { энергіею идти впередъ } \\
\text { и взирать на будущность } \\
\text { открывающуюся передъ } \\
\text { нами. }\end{array}$ & $\begin{array}{l}\text { Потомъ остановившись } \\
\text { на объясненіи и описаніи } \\
\text { понятій «сиастливьй домъ, } \\
\text { счастливый бракъ», ко- } \\
\text { торые онъ называеть } \\
\text { «подобіемъ неба на землп», } \\
\text { почтенный деканъ гово- } \\
\text { ритъ что «бракъ, гдъ бы } \\
\text { онъ ни совершался, въ вы- } \\
\text { сокихъ ли положеніяхъ } \\
\text { жизни, или въ смирен- } \\
\text { ньхъ, есть не только сліяніе } \\
\text { двухъ человъческихъ душъ } \\
\text { для взаимнаго общенія } \\
\text { и помощи, не только по- } \\
\text { стоянный обмънъ чис- } \\
\text { тьйшаго счастья, но так- } \\
\text { же новый источникъ } \\
\text { обновленія и спасенія; } \\
\text { да, это есть какъ бы } \\
\text { посльдній великій при- } \\
\text { зывъ разъ навсегда от- } \\
\text { бросить отъ себя про- } \\
\text { шедшее со всъми его } \\
\text { заблужденіями, ошиб- } \\
\text { ками и безуміемъ, от- } \\
\text { бросить далеко, далеко, } \\
\text { назадъ, чтобы съ новы- } \\
\text { ми надеждами, новымъ } \\
\text { мужествомъ и новою } \\
\text { энергіею идти впередъ } \\
\text { и взирать на будущность } \\
\text { открывающуюся передъ } \\
\text { нами». }\end{array}$ & $\begin{array}{l}\text { Дословный перевод выле- } \\
\text { ленного фрагмента: «...но } \\
\text { и новое начало жизни, } \\
\text { новая отправная точка } \\
\text { полезности (полноцен- } \\
\text { ности)». }\end{array}$ \\
\hline $\begin{array}{l}\text { Think, also, of what is } \\
\text { meant by a happy home. }\end{array}$ & $\begin{array}{l}\text { Только тогда вы пойме- } \\
\text { те какой смысль имъетъ } \\
\text { слово: счастливый домъ! }\end{array}$ & & $\begin{array}{l}\text { Дословный перевод въце- } \\
\text { ленного предложения: «По- } \\
\text { думайте также о значении } \\
\text { слова счастливый дом». }\end{array}$ \\
\hline
\end{tabular}




\begin{tabular}{|c|c|c|c|}
\hline $\begin{array}{c}\text { Проповедь Стенли } \\
\text { (на англ. языке) }\end{array}$ & $\begin{array}{c}\text { Перевод } \\
\text { К. П. Победоноцева } \\
(\text { Гражданинб. 1874. } \\
\text { № 3. С. 78-81) }\end{array}$ & $\begin{array}{c}\text { Редакционное } \\
\text { изложение } \\
\text { (Гражданинъ. 1874. } \\
\text { № 2. С. 37-39) }\end{array}$ & Комментарии \\
\hline $\begin{array}{l}\text { It is the best likeness of } \\
\text { Heaven - a home where } \\
\text { husband and wife, father } \\
\text { and mother, brother and } \\
\text { sister, child and parent, each } \\
\text { in their several ways, help } \\
\text { each the other forwards, in } \\
\text { their difficult courses, as no } \\
\text { other human being can, for } \\
\text { none outside the circle of } \\
\text { our own home has the same } \\
\text { opportunities, none else has } \\
\text { known so well the character of } \\
\text { any other, none else has such } \\
\text { an interest at stake in the } \\
\text { welfare, the fame, the grace, } \\
\text { and the goodness of any one } \\
\text { else, as we have in the welfare } \\
\text { of those who are bone of our } \\
\text { bone and flesh of our flesh, } \\
\text { in whose happiness and glory } \\
\text { we ourselves become happy } \\
\text { and glorious, in whose mi- } \\
\text { sery we should become mi- } \\
\text { serable; by whose selfishness, } \\
\text { or weakness, or worldliness } \\
\text { we should be dragged down } \\
\text { to earth - by whose purity } \\
\text { other, as long as they both } \\
\text { shall live; when father and } \\
\text { mother part with the joy } \\
\text { of their eyes, the pride of } \\
\text { we are raised up to duty, to } \\
\text { Heaven, and to God. } \\
\text { solemn separation, when } \\
\text { such a world of blessed- } \\
\text { ness for ourselves and for } \\
\text { others, is the rich return, } \\
\text { is the only return, which } \\
\text { God in His merciful Pro- } \\
\text { vidence, which man in his } \\
\text { grateful affection, can make } \\
\text { for that rending asunder } \\
\text { }\end{array}$ & 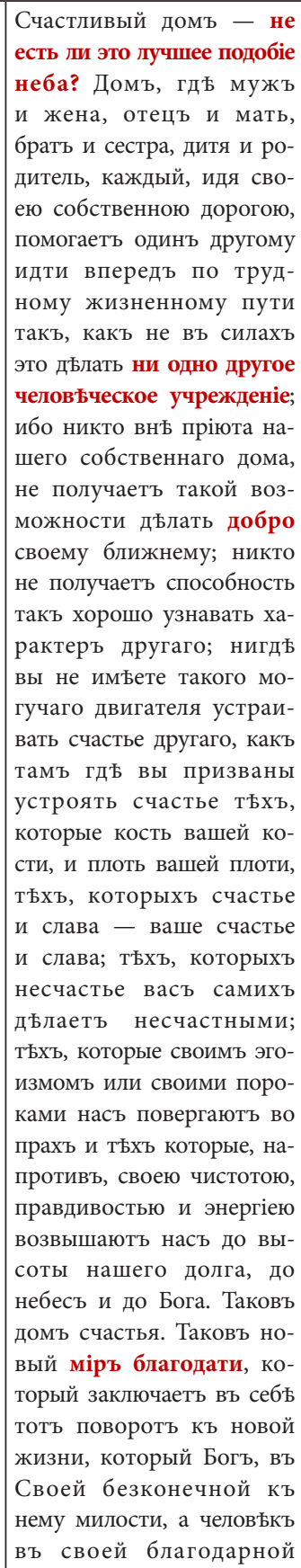 & & $\begin{array}{l}\text { Дословный перевод выде- } \\
\text { ленного фрагмента: «Это } \\
\text { лучшее подобие Царствия } \\
\text { небесного - дом, где...». } \\
\\
\text { Выцеленная фраза дослов- } \\
\text { но: «ни одно другое чело- } \\
\text { веческое существо». Ср. } \\
\text { буквальный перевод: аs по } \\
\text { отһег hитап bеing - ни- } \\
\text { кто другой } \\
\text { Дословный перевод выцелен- } \\
\text { ного фрагмента: «...благо- } \\
\text { состояние, славу, милость } \\
\text { и доброту». }\end{array}$ \\
\hline
\end{tabular}




\begin{tabular}{|c|c|c|c|}
\hline $\begin{array}{c}\text { Проповедь Стенли } \\
\text { (на англ. языке) }\end{array}$ & $\begin{array}{c}\text { Перевод } \\
\text { К. П. Победоносцева } \\
\text { (Гражданинб. 1874. } \\
\text { № 3. С. 78-81) }\end{array}$ & $\begin{array}{c}\text { Редакционное } \\
\text { изложение } \\
\text { (Гражданинъ. 1874. } \\
\text { № 2. С. 37-39) }\end{array}$ & Комментарии \\
\hline $\begin{array}{l}\text { their hearts, in the sure and } \\
\text { certain hope that out of this } \\
\text { bitter pang a new happiness } \\
\text { shall be born - a new soul, } \\
\text { not unclothed, but clothed } \\
\text { upon shall be breathed } \\
\text { into the treasure already so } \\
\text { precious - a new sphere } \\
\text { opened for the unfolding of } \\
\text { those gifts and graces which } \\
\text { shall make the home that } \\
\text { is to be created as blessed } \\
\text { as that which has been left } \\
\text { behind. }\end{array}$ & $\begin{array}{l}\text { любви, можетъ совер- } \\
\text { шить, разрывая навсегда } \\
\text { самыя дорогія для него } \\
\text { связи, и готовясь къ той } \\
\text { торжественной разлукъ, } \\
\text { когда жена или мужъ } \\
\text { призваны для брака } \\
\text { «оставить мать и отца } \\
\text { и прилъпиться другъ } \\
\text { къ другу»; да, и если от- } \\
\text { ецъ и мать разлучаются } \\
\text { съ лучшею радостью ихъ } \\
\text { жизни, съ сокровищемъ } \\
\text { своего сердца, то разлуча- } \\
\text { ются въ твердой надеждъ } \\
\text { что отъ этого горькаго } \\
\text { для нихъ бремени разлу- } \\
\text { ки родится новое счастье, } \\
\text { новая душа, и разцвътъ } \\
\text { этой новой души будетъ } \\
\text { сокровищемъ не менъе } \\
\text { дорогимъ, чьмъ то кото- } \\
\text { раго они лишились. } \\
\text { Да, эти дары благо- } \\
\text { дати открываютъ новый } \\
\text { міръ, и содълываютъ его } \\
\text { столь же полнымъ радо- } \\
\text { стей, какъ тотъ который } \\
\text { они покидаютъ. }\end{array}$ & & \\
\hline $\begin{array}{l}\text { And assuredly the hope } \\
\text { thus bound up in this gayest } \\
\text { yet gravest of all earthly } \\
\text { ordinances, wherever ce- } \\
\text { lebrated, becomes fraught } \\
\text { with a yet deeper joy and } \\
\text { a yet deeper seriousness } \\
\text { when it carries with it not } \\
\text { only the union of two lo- } \\
\text { ving human souls, but also } \\
\text { the friendly meeting of two } \\
\text { mighty nations. }\end{array}$ & $\begin{array}{l}\text { И вотъ, укрђпляемые } \\
\text { тою надеждою, которая } \\
\text { есть смысль сего радост- } \\
\text { наго и вмъстъ съ тъмъ } \\
\text { серьознъйшаго изъ обря- } \\
\text { довъ, когда либо въ жиз- } \\
\text { ни нами совершаемыхъ, } \\
\text { мы въ то же время еще } \\
\text { болъе радуемся, и еще } \\
\text { серьознъе смотримъ на } \\
\text { сегодняшнее торжество } \\
\text { потому, что оно не толь- } \\
\text { ко есть сочетаніе двухъ } \\
\text { человъческихъ сердецъ, } \\
\text { но есть какъ бы союзъ } \\
\text { мира двухъ могуще- } \\
\text { ственныхъ націй. }\end{array}$ & $\begin{array}{l}\text { Выяснивъ понятіе } \\
\text { о бракъ и опредъливъ } \\
\text { его обязанности пропо- } \\
\text { въдникъ говоритъ: «Мы } \\
\text { въ то же время еще } \\
\text { болъе радуемся, и еще } \\
\text { серьознъе смотримъ на } \\
\text { сегодняшнее торжество } \\
\text { потому, что оно не толь- } \\
\text { ко есть сочетаніе двухъ } \\
\text { человъческихъ сердецъ, } \\
\text { но есть какъ бы союзъ } \\
\text { мира двухъ могуществен- } \\
\text { ныхъ націй. }\end{array}$ & $\begin{array}{l}\text { Дословный перевод фраг- } \\
\text { мента: «И, конечно, на- } \\
\text { дежда, связанная таким } \\
\text { образом с этим радост- } \\
\text { ным и одновременно се- } \\
\text { рьезнейшим из всех зем- } \\
\text { ных обрядов, когда-либо } \\
\text { праздновавшихся, стано- } \\
\text { вится наполненной еще } \\
\text { большей радостью и еще } \\
\text { большей серьезностью, } \\
\text { когда он влечет за собой не } \\
\text { только единение двух лю- } \\
\text { бящих человеческих душ, } \\
\text { но также дружественную } \\
\text { встречу двух могуще- } \\
\text { ственных народов». }\end{array}$ \\
\hline
\end{tabular}




\begin{tabular}{|c|c|c|c|}
\hline $\begin{array}{c}\text { Проповедь Стенли } \\
\text { (на англ. языке) }\end{array}$ & $\begin{array}{c}\text { Перевод } \\
\text { К. П. Победоносцева } \\
\text { (Гражданинб. 1874. } \\
\text { № 3. С. 78-81) }\end{array}$ & $\begin{array}{c}\text { Редакционное } \\
\text { изложение } \\
\text { (Гражданинъ. 1874. } \\
\text { № 2. С. 37-39) }\end{array}$ & Комментарии \\
\hline $\begin{array}{l}\text { It is one of the wonderful } \\
\text { consequences and illustra- } \\
\text { tions of the importance of } \\
\text { this holy ordinance, that } \\
\text { when undertaken not unad- } \\
\text { visedly, lightly, or wantonly, } \\
\text { but reverently and advisedly } \\
\text { in the fear of God, and in } \\
\text { pure love one for another, it } \\
\text { sanctifies and unites all that } \\
\text { it touches. It gilds the cottage } \\
\text { of the humblest peasant, } \\
\text { it intertwines and knits } \\
\text { together the intercourse of } \\
\text { ancient Empires. And this } \\
\text { becomes the more striking } \\
\text { in proportion as the nations } \\
\text { thus brought together have } \\
\text { stood far asunder at the two } \\
\text { extremities of Europe, the } \\
\text { two poles of Christian civi- } \\
\text { lization. }\end{array}$ & $\begin{array}{l}\text { Въ этомъ-то и заклю- } \\
\text { чается чудесное дъйствіе } \\
\text { сего важнаго обряда, что } \\
\text { когда онъ совершается не } \\
\text { необдуманно, не легко- } \\
\text { мысленно, не въ шутку, } \\
\text { но съ благоговъньемъ } \\
\text { и въ страхъ Божіемъ, } \\
\text { и въ чистой любви од- } \\
\text { ного къ другому, - онъ } \\
\text { освящаетъ и объединя- } \\
\text { етъ все что къ нему при- } \\
\text { касается - онъ золотить } \\
\text { хижину бъднъйшаго кре- } \\
\text { стьянина; и если прежде } \\
\text { дъйствіе его связывало } \\
\text { и объединяло между со- } \\
\text { бою государства на ихъ } \\
\text { общемъ историческомъ } \\
\text { пути, то еще болъе благо- } \\
\text { творнымъ кажется намъ } \\
\text { его связующее дъйствіе, } \\
\text { когда оно устанавлива- } \\
\text { етъ отношенія между } \\
\text { государствами, стояв- } \\
\text { шими другъ отъ друга } \\
\text { раздъленными, - какъ } \\
\text { два полюса христіанской } \\
\text { цивилизаціи на двухъ } \\
\text { концахъ Европы. }\end{array}$ & $\begin{array}{l}\text { Въ этомъ-то и заклю- } \\
\text { чается чудесное дъйствіе } \\
\text { сего важнаго обряда, что } \\
\text { когда онъ совершается не } \\
\text { необдуманно, не легко- } \\
\text { мысленно, не въ шутку, } \\
\text { но съ благоговъньемъ } \\
\text { и въ страхъ Божіемъ, и въ } \\
\text { чистой любви одного къ } \\
\text { другому, - онъ освяща- } \\
\text { етъ и объединяетъ все, } \\
\text { что къ нему прикасает- } \\
\text { ся - онъ золотитъ хи- } \\
\text { жину бъднъйшаго кре- } \\
\text { стьянина; и если прежде } \\
\text { дъйствіе его связывало } \\
\text { и объединяло между со- } \\
\text { бою государства на ихъ } \\
\text { общемъ историческомъ } \\
\text { пути, то еще болъе благо- } \\
\text { творнымъ кажется намъ } \\
\text { его связующее дъйствіе, } \\
\text { когда оно устанавли- } \\
\text { ваетъ отношенія между } \\
\text { государствами, стояв- } \\
\text { шими другъ отъ друга } \\
\text { раздъленными, - какъ } \\
\text { два полюса христіанской } \\
\text { цивилизаціи на двухъ } \\
\text { концахъ Европы. }\end{array}$ & $\begin{array}{l}\text { Дословный перевод выљде- } \\
\text { ленного фрагмента: «Это } \\
\text { одно из чудесных прояв- } \\
\text { лений и примеров важ- } \\
\text { ности этого святого об- } \\
\text { ряда». } \\
\\
\text { Дословный перевод вьље- } \\
\text { ленного фрагмента: "... } \\
\text { он устанавливает связи } \\
\text { и объединяет древние } \\
\text { Империи. И это становит- } \\
\text { ся еще более примечатель- } \\
\text { ным ввиду того, что объе- } \\
\text { диненные таким образом } \\
\text { народы, столи на двух раз- } \\
\text { ных концах Европы, двух } \\
\text { полюсах христианского } \\
\text { мира». }\end{array}$ \\
\hline $\begin{array}{l}\text { It is now almost exactly eight } \\
\text { hundred years since the last } \\
\text { nuptial alliance between the } \\
\text { Royal Houses of England } \\
\text { and of Russia; when, in the } \\
\text { close of the eleventh centu- } \\
\text { ry, the greatest of the early } \\
\text { Russian Princes, Vladimir } \\
\text { Monomachus, wooed and } \\
\text { won the Princess Gytha, the } \\
\text { daughter of King Harold, } \\
\text { the Last of the Saxons. How } \\
\text { little could either Mo- } \\
\text { narch then have imagined } \\
\text { the world-wide progress } \\
\text { which each people would } \\
\text { have made before another } \\
\text { Prince and another Prin- } \\
\text { cess of either realm should } \\
\text { cement by a sacred family }\end{array}$ & $\begin{array}{l}\text { Сегодня празднуемый } \\
\text { нами брачный союзъ не } \\
\text { имъетъ себъ подобна- } \\
\text { го въ Европъ въ теченіе } \\
800 \text { льтъ; посльдній } \\
\text { бракъ между королев- } \\
\text { скимъ англійскимъ до- } \\
\text { момъ и Россіею теряется } \\
\text { въ туманъ отдаленной } \\
\text { отъ насъ исторіи, когда } \\
\text { величайшій изъ древ- } \\
\text { нихъ Русскихъ Князей, } \\
\text { Владиміръ Мономахъ, } \\
\text { просилъ руки Принцес- } \\
\text { сы Гитъ, дочери Гарольда, } \\
\text { послъдняго изъ саксон- } \\
\text { скихъ королей. } \\
\text { Какъ мало тотъ } \\
\text { и другой монархъ могли } \\
\text { провидъть тъ великія }\end{array}$ & $\begin{array}{l}\text { Сегодня празднуемый } \\
\text { нами брачный союзъ не } \\
\text { имъетъ себъ подобна- } \\
\text { го въ Европъ въ теченіе } \\
800 \text { льтъ; посльдній } \\
\text { бракъ между королев- } \\
\text { скимъ англійскимъ до- } \\
\text { момъ и Россіею теряется } \\
\text { въ туманъ отдаленной } \\
\text { отъ насъ исторіи, когда } \\
\text { величайшій изъ древ- } \\
\text { нихъ Русскихъ Князей, } \\
\text { Владиміръ Мономахъ, } \\
\text { просилъ руки Принцес- } \\
\text { сы Гитъ, дочери Гарольда, } \\
\text { посльдняго изъ саксон- } \\
\text { скихъ королей. } \\
\text { Какъ мало тотъ } \\
\text { и другой монархъ мог- } \\
\text { ли провидъть тъ великія }\end{array}$ & $\begin{array}{l}\text { Дословныци перевод выљде- } \\
\text { ленного фрагмента: «Едва } \\
\text { ли могли представить } \\
\text { себе оба монарха мировое } \\
\text { развитие, которым пошли } \\
\text { бы их народы при другом } \\
\text { Князе и Княжне в обоих } \\
\text { царствах, не соедини они } \\
\text { священным браком союза } \\
\text { двух государств». }\end{array}$ \\
\hline
\end{tabular}




\begin{tabular}{|c|c|c|c|}
\hline $\begin{array}{c}\text { Проповедь Стенли } \\
\text { (на англ. языке) }\end{array}$ & $\begin{array}{c}\text { Перевод } \\
\text { К. П. Победоносцева } \\
\text { (Гражданинъ. } 1874 . \\
\text { № 3. С. 78-81) }\end{array}$ & $\begin{array}{c}\text { Редакционное } \\
\text { изложение } \\
\text { (Гражданинъ. 1874. } \\
\text { № 2. С. 37-39) }\end{array}$ & Комментарии \\
\hline \multirow[t]{2}{*}{$\begin{array}{l}\text { union the union of the two } \\
\text { countries; that the small is- } \\
\text { land on the confines of the } \\
\text { Western Ocean, struggling } \\
\text { with difficulty to hold its } \\
\text { own against invaders from } \\
\text { every quarter, should have } \\
\text { become the mistress of the } \\
\text { seas and "hold the gor- } \\
\text { geous East in fee"; that the } \\
\text { barbarous principality in } \\
\text { the centre of the wild Sla- } \\
\text { vonic forests should have } \\
\text { grown up into the mighty } \\
\text { civilized Empire which now } \\
\text { almost joins hands with the } \\
\text { descendants of that distant } \\
\text { Anglo-Saxon race, alike in } \\
\text { the heart of Asia and on the } \\
\text { borders of America. What } \\
\text { a prospect of possible great- } \\
\text { ness, of infinite advance in } \\
\text { the ages yet to come, is sug- } \\
\text { gested by that retrospect of } \\
\text { the ages that are past and } \\
\text { gone. }\end{array}$} & $\begin{array}{l}\text { судьбы, коихъ соверши- } \\
\text { телями въ исторіи міра } \\
\text { явятся объ эти націи, } \\
\text { при другомъ принцъ } \\
\text { и при другой княжнъ, } \\
\text { и то значеніе, которое } \\
\text { посредствомъ семейной } \\
\text { связи получитъ союзъ } \\
\text { этихъ двухъ государствъ. } \\
\text { И въ правду, могли ли они } \\
\text { предвидъть что маленькій } \\
\text { островъ гдъ то въ дали } \\
\text { океана, открытый для } \\
\text { всъхъ вътровъ и для } \\
\text { всякаго вооруженнаго } \\
\text { нападенія, сдълается вла- } \\
\text { дыкою морей и страхомъ } \\
\text { изнъженнаго Востока, } \\
\text { и что княжество въ ди- } \\
\text { кихъ лъсахъ Славянскихъ } \\
\text { выростетъ въ могуще- } \\
\text { ственное и образованное } \\
\text { государство, протягива- } \\
\text { ющее руку преемникамъ } \\
\text { Англо-Саксонской расы } \\
\text { въ центръ Азіи и на гра- } \\
\text { ницахъ Америки. } \\
\text { Какое предвидъніе въ } \\
\text { грядущемъ величія и без- } \\
\text { конечнаго успъха внуша- } \\
\text { етъ намъ этотъ взглядъ } \\
\text { брошенный на вька давно } \\
\text { уже минувшіе! }\end{array}$ & 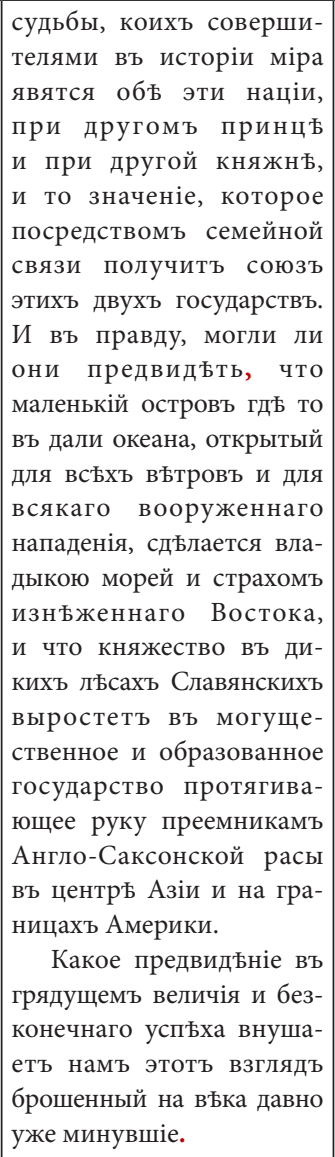 & $\begin{array}{l}\text { Дословный перевод выделен- } \\
\text { ного фрагмента: «и под- } \\
\text { чинит великолепный Вос- } \\
\text { ток; что варварское княже- } \\
\text { ство...». }\end{array}$ \\
\hline & $\begin{array}{l}\text { Если оть той поры } \\
\text { понынъ пилось «доброе } \\
\text { вино» христіанскаго про- } \\
\text { свъщенія, теперь еще } \\
\text { лучшее вино ждетъ } \\
\text { впереди дътей нашихъ } \\
\text { дбтей! }\end{array}$ & $\begin{array}{l}\text { Если отъ той поры } \\
\text { понынъ пилось «доброе } \\
\text { вино» христіанскаго про- } \\
\text { свЂщенія, теперь еще луч- } \\
\text { шее вино ждетъ впереди } \\
\text { дътей нашихъ дЂтей!» }\end{array}$ & $\begin{array}{l}\text { Выцеленный фрагмент до- } \\
\text { бавлен автором перевода. }\end{array}$ \\
\hline $\begin{array}{l}\text { And in proportion to the } \\
\text { grandeur achieved by } \\
\text { the two nations which } \\
\text { have thus once more ap- } \\
\text { proached each other is the } \\
\text { importance of any event } \\
\text { which promotes this mu- } \\
\text { tual understanding and } \\
\text { harmony. }\end{array}$ & $\begin{array}{l}\text { Да, степень величія } \\
\text { достигнутаго обоими на- } \\
\text { родами составляетъ еще } \\
\text { болъе крђпкое звъно, } \\
\text { усиливающее ихъ взаим- } \\
\text { ное согласіе и гармонію. }\end{array}$ & & $\begin{array}{l}\text { Дословный перевод фраг- } \\
\text { мента: «Важность любого } \\
\text { события, способствующе- } \\
\text { го взаимному пониманию } \\
\text { и гармонии, пропорцио- } \\
\text { нально величию, достиг- } \\
\text { нутому обеими народами, } \\
\text { сблизившимися вновь». }\end{array}$ \\
\hline
\end{tabular}




\begin{tabular}{|c|c|c|c|}
\hline $\begin{array}{c}\text { Проповедь Стенли } \\
\text { (на англ. языке) }\end{array}$ & $\begin{array}{c}\text { Перевод } \\
\text { К. П. Победоносцева } \\
(\text { Гражданинъ. } 1874 . \\
\text { № 3. С. 78-81) }\end{array}$ & $\begin{array}{c}\text { Редакционное } \\
\text { изложение } \\
\text { (Гражданинъ. 1874. } \\
\text { № 2. С. 37-39) }\end{array}$ & Комментарии \\
\hline $\begin{array}{l}\text { They have known each } \\
\text { other in war, both as friends } \\
\text { and foes. With chivalrous } \\
\text { respect they have seen and } \\
\text { tried each other's strength, } \\
\text { beside beleaguered fortress } \\
\text { and on hard-won bat- } \\
\text { tle-field. They have listened } \\
\text { to the inspiring accents of } \\
\text { each other's literature and } \\
\text { science. Their commerce } \\
\text { and their enterprise have } \\
\text { embraced the world- Their } \\
\text { Churches have exchanged } \\
\text { many a friendly message, } \\
\text { and breathed many a kindly } \\
\text { hope for the great „Hereaf- } \\
\text { ter, which, if each be true } \\
\text { to itself, assuredly awaits } \\
\text { them both. }\end{array}$ & $\begin{array}{l}\text { Они встрбчались въ } \\
\text { войнахъ какъ друзья и не- } \\
\text { други, съ рыцарскимъ } \\
\text { уваженіемъ другъ къ } \\
\text { другу мърили свои силы } \\
\text { на чистомъ полъ и при } \\
\text { осадъ кръпостей. Они } \\
\text { внимали вдохновеннымъ } \\
\text { звукамъ своихъ лите- } \\
\text { ратуръ и своихъ наукъ. } \\
\text { Ихъ промышленность } \\
\text { и предпріятія охватили } \\
\text { весь свътъ, ихъ церкви } \\
\text { обмънивались не разъ } \\
\text { дружескими посланіями } \\
\text { и объ питались сладкой } \\
\text { надеждой достичь велика- } \\
\text { го будущаго, ожидающа- } \\
\text { го ихъ обоихъ, если оно } \\
\text { только возможно, }\end{array}$ & & $\begin{array}{l}\text { Дословный перевод выце- } \\
\text { ленного фрагмента: «на } \\
\text { с трудом отвоеванном } \\
\text { поле битвы» } \\
\text { Дословный перевод выде- } \\
\text { ленного фрагмента: «Их } \\
\text { торговля и предприятия». } \\
\text { Дословный перевод выце- } \\
\text { ленного фрагмента: «если } \\
\text { каждый будет верен себе». }\end{array}$ \\
\hline $\begin{array}{l}\text { And now comes that more } \\
\text { personal, genial, cordial } \\
\text { union, which brings the } \\
\text { two nations as it were, face } \\
\text { to face, and hand in hand, } \\
\text { in the plighted troth of } \\
\text { those whom each desires } \\
\text { to regard as its living rep- } \\
\text { resentative. }\end{array}$ & $\begin{array}{l}\text { и вотъ теперь эти судь- } \\
\text { бы, столь часто разъеди- } \\
\text { няемыя, скръпляются } \\
\text { снова. И отношенія, } \\
\text { которыя люди церкви, } \\
\text { представители купе- } \\
\text { ческаго званія, армія } \\
\text { и лица государственныя } \\
\text { старались по временамъ } \\
\text { оживлять, какъ бы заго- } \\
\text { раются теперь съ новою } \\
\text { силою посредствомъ } \\
\text { личнаго, радостнаго, } \\
\text { дружескаго союза, ставя- } \\
\text { щаго объ націи лицомъ } \\
\text { къ лицу и рука объ руку } \\
\text { въ союзъ тъхъ, которые } \\
\text { желали бы служить въ } \\
\text { теченіе всей своей жиз- } \\
\text { ни олицетворенными } \\
\text { представителями своихъ } \\
\text { націй. Если было бы воз- } \\
\text { можно древнимъ нор- } \\
\text { манамъ, родоначальни- } \\
\text { камъ объихъ династій, } \\
\text { Рюрику, первому осно- } \\
\text { вателю Россійскаго Госу- } \\
\text { дарства, или позднъе - } \\
\text { Петру, могуществен- } \\
\text { ному устроителю его, }\end{array}$ & & 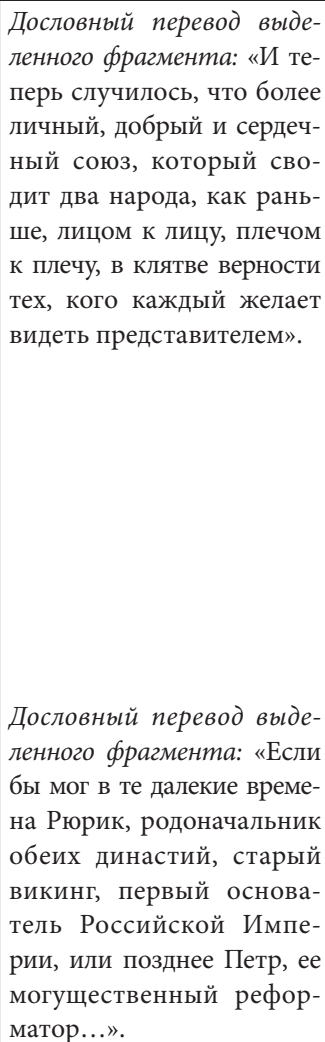 \\
\hline
\end{tabular}




\begin{tabular}{|c|c|c|c|}
\hline $\begin{array}{c}\text { Проповедь Стенли } \\
\text { (на англ. языке) }\end{array}$ & $\begin{array}{c}\text { Перевод } \\
\text { К. П. Победоноцева } \\
(\text { Гражданинъ. 1874. } \\
\text { № 3. С. 78-81) }\end{array}$ & $\begin{array}{c}\text { Редакционное } \\
\text { изложение } \\
\text { (Гражданинб. 1874. } \\
\text { № 2. С. 37-39) }\end{array}$ & Комментарии \\
\hline $\begin{array}{l}\text { the daughters of their race, } \\
\text { they would have rejoiced } \\
\text { that the alliance should have } \\
\text { been formed with a sailor } \\
\text { Prince, the pride of that gal- } \\
\text { lant profession which wag, } \\
\text { to that early chief, and yet } \\
\text { more to that wonderful cre- } \\
\text { ator of the Russian navy, so } \\
\text { deep a delight, so passio- } \\
\text { nate an interest. Had Alfred } \\
\text { the Great looked onward } \\
\text { for a partner who should } \\
\text { ennoble the career of the } \\
\text { first English Prince, the only } \\
\text { one of all the lengthened } \\
\text { line who, coming to man's } \\
\text { estate, has borne that glori- } \\
\text { ous name - he, the wisest } \\
\text { and best of England's Kings, } \\
\text { would have welcomed with } \\
\text { no ordinary gladness, in } \\
\text { this union of the West and } \\
\text { the East, the advancement } \\
\text { of those designs, which he } \\
\text { entertained so far beyond } \\
\text { his age, for bringing his An- } \\
\text { glo-Saxon realm into con- } \\
\text { tact with the distant races of } \\
\text { Asia; he would have blessed } \\
\text { the day which would give } \\
\text { an additional pledge of } \\
\text { the foremost Churches of } \\
\text { Christendom. }\end{array}$ & $\begin{array}{l}\text { опредълить участь одной } \\
\text { изъ дочерей ихъ рода, то } \\
\text { нътъ сомнънія, они бы } \\
\text { обрадовались брачному } \\
\text { сочетанію съ княземъ- } \\
\text { морякомъ, и возрадова- } \\
\text { лись бы съ чувствомъ } \\
\text { гордости того благород- } \\
\text { наго ремесла, которое } \\
\text { было страстно-любомою } \\
\text { заботою, какъ древняго } \\
\text { князя Рюрика, такъ еще } \\
\text { болье и славнаго основа- } \\
\text { теля русскаго морскаго } \\
\text { могущества. Также, если } \\
\text { бы Альфредъ Великій } \\
\text { могъ бы въ отдаленномъ } \\
\text { будущемъ избрать под- } \\
\text { ругу, которая бы озарила } \\
\text { и украсила жизнь пер- } \\
\text { ваго Англійскаго Кня- } \\
\text { зя - единственнаго изъ } \\
\text { всъхъ послъдующихъ } \\
\text { Англійскихъ Князей, ко- } \\
\text { торый украсился этимъ } \\
\text { славнымъ именемъ - } \\
\text { онъ, умнъйшій и лучшій } \\
\text { изъ Королей Англіи, воз- } \\
\text { радовался бы этому сою- } \\
\text { зу Востока съ Западомъ, } \\
\text { этому предвъстнику } \\
\text { осуществленія той меч- } \\
\text { ты, которую прозръвалъ } \\
\text { онъ въ будущемъ - } \\
\text { сближенія его Англо-Сак- } \\
\text { сонскаго царства съ отда- } \\
\text { ленными народами Азіи. } \\
\text { Онъ привътствовалъ } \\
\text { бы этотъ счастливый } \\
\text { день какъ залогъ мира } \\
\text { и благоденствія между } \\
\text { первенствующими наро- } \\
\text { дами и другъ другу сочув- } \\
\text { ствующими церквами. }\end{array}$ & $\begin{array}{l}\text { Сказавъ эти слова, } \\
\text { проповъдникъ указыва- } \\
\text { еть на тъ черты, въ кото- } \\
\text { рыхъ онъ видить общеніе } \\
\text { Россіи съ Англіею, и вос- } \\
\text { крешая передъ слуша- } \\
\text { телями историческія } \\
\text { личности Петра I-го } \\
\text { и Альфреда Великаго, } \\
\text { становитъ ихъ какъ бы } \\
\text { передъ нынъшнимъ } \\
\text { событіемъ, и говорить } \\
\text { что оба привътстовали } \\
\text { бы этоть счастливый } \\
\text { день, какъ залогъ мира } \\
\text { и благоденствія между } \\
\text { первенствующими наро- } \\
\text { дами и другъ другу сочув- } \\
\text { ствующими церквами. }\end{array}$ & $\begin{array}{l}\text { Дословный перевод выделен- } \\
\text { ного фрагмента: «...воз- } \\
\text { радовался бы в этом союзе } \\
\text { Запада с Востоком продви- } \\
\text { жению планов, которые он } \\
\text { лелеял издавна». } \\
\\
\text { Выцеленная фраза дослов- } \\
\text { но: «дополнительный за- } \\
\text { лог мира». } \\
\text { Вьделенная фраза дослов- } \\
\text { но: «...и главными церква- } \\
\text { ми христианского мира». }\end{array}$ \\
\hline
\end{tabular}




\begin{tabular}{|c|c|c|c|}
\hline $\begin{array}{c}\text { Проповедь Стенли } \\
\text { (на англ. языке) }\end{array}$ & $\begin{array}{c}\text { Перевод } \\
\text { К. П. Победоносцева } \\
\text { (Гражданинъ. 1874. } \\
\text { № 3. С. 78-81) }\end{array}$ & $\begin{array}{c}\text { Редакционное } \\
\text { изложение } \\
\text { (Гражданинъ. 1874. } \\
\text { № 2. С. 37-39) }\end{array}$ & Комментарии \\
\hline $\begin{array}{l}\text { May the blessing of En- } \\
\text { gland, as represented this } \\
\text { day in this long-established } \\
\text { seat of English piety in Rus- } \\
\text { sia, descend on the union } \\
\text { which shall within this week } \\
\text { he accomplished! }\end{array}$ & $\begin{array}{l}\text { Посредствомъ этого до- } \\
\text { ма молитвы, такъ давно } \\
\text { существующаго въ Россіи, } \\
\text { да низойдетъ же благосло- } \\
\text { веніе Англіи на союзъ, } \\
\text { который въ продолженіи } \\
\text { этой недъли долженъ со- } \\
\text { вершиться. }\end{array}$ & $\begin{array}{l}\text { «Посредствомъ этого до- } \\
\text { ма молитвы, такъ давно } \\
\text { существующаго въ Россіи, } \\
\text { да низойдетъ же благосло- } \\
\text { веніе Англіи на союзъ, } \\
\text { который въ продолженіи } \\
\text { этой недъли долженъ со- } \\
\text { вершиться». }\end{array}$ & \\
\hline $\begin{array}{l}\text { May the touching farewells } \\
\text { from the shores of the Neva } \\
\text { be echoed by the cordial wel- } \\
\text { come from the shores of the } \\
\text { Thames to her whose very } \\
\text { bearing and countenance } \\
\text { shall for ever remind us of } \\
\text { the tender love which has } \\
\text { watched over her in this her } \\
\text { native land and will foilow } \\
\text { her in her adopted home: }\end{array}$ & $\begin{array}{l}\text { Да откликнутся трога- } \\
\text { тельнымъ прощаніемъ на } \\
\text { берегахъ Невы радостныя } \\
\text { привътствія на берегахъ } \\
\text { Темзы той, которой об- } \\
\text { разъ намъ всегда будетъ } \\
\text { напоминать н ъ жную } \\
\text { о ней заботу охранявшей } \\
\text { ее родины, - заботу кото- } \\
\text { рая будетъ слъдить за ней } \\
\text { въ ея новой отчизнъ! }\end{array}$ & & $\begin{array}{l}\text { Сp. буквальный перевод: } \\
\text { bearing and countenance - } \\
\text { осанка и выражение лица } \\
\text { Выцеленная фраза бук- } \\
\text { вально: «будет сопровож- } \\
\text { дать ее». }\end{array}$ \\
\hline $\begin{array}{l}\text { That was an affecting and } \\
\text { all-sufficing commenda- } \\
\text { tion with which the Isra- } \\
\text { elite Mother in old times } \\
\text { gave her "one only daugh- } \\
\text { ter" to the young traveller } \\
\text { that came by an angel's } \\
\text { guidance to seek his bride } \\
\text { in a distant land. 'Behold," } \\
\text { she said, "I commit my } \\
\text { daughter unto thee of spe- } \\
\text { cial trust." (Tobit. VI. 10. } \\
\text { X. 12). Of special trust, } \\
\text { indeed, is the treasure thus } \\
\text { given to our honourable } \\
\text { keeping. }\end{array}$ & & & 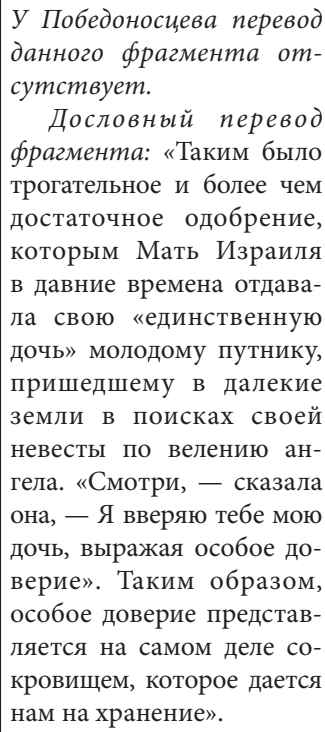 \\
\hline $\begin{array}{l}\text { May every Englishman } \\
\text { and Englishwoman whose } \\
\text { hearts are touched by the } \\
\text { thoughts of this week, feel } \\
\text { bound, so far as in them, } \\
\text { lies, to do their utmost to } \\
\text { make the future worthy of } \\
\text { the promise of this magni- } \\
\text { ficent beginning. }\end{array}$ & $\begin{array}{l}\text { Пусть всякій сынъ } \\
\text { Англіи, гдъ бы онъ ни } \\
\text { былъ, который сердцемъ } \\
\text { понялъ все происходя- } \\
\text { щее въ эти дни, да помо- } \\
\text { жетъ и онъ, на сколько } \\
\text { можетъ, чтобы будущее } \\
\text { было достойно настоя- } \\
\text { щаго событія. }\end{array}$ & $\begin{array}{l}\text { Затъмъ напомнивъ } \\
\text { словами изъ Товіи тъ обя- } \\
\text { занности которыя анге- } \\
\text { ломъ возложены были } \\
\text { на юнаго странника, } \\
\text { пришедшаго за женою } \\
\text { въ отдаленную страну, } \\
\text { проповъдникъ заклю- } \\
\text { чилъ свою проповъдь } \\
\text { слъдующими словами: }\end{array}$ & $\begin{array}{l}\text { Дословный перевод фраг- } \\
\text { мента: «Пусть всякий } \\
\text { сын и дочь Англии, серд- } \\
\text { це коих тронуто мыслями } \\
\text { этой недели, почувствуют } \\
\text { себя обязанными сделать } \\
\text { все от них возможное, } \\
\text { чтобы будущее стало до- } \\
\text { стойным такого много- } \\
\text { обещающего начала». }\end{array}$ \\
\hline
\end{tabular}




\begin{tabular}{|c|c|c|c|}
\hline $\begin{array}{c}\text { Проповедь Стенли } \\
\text { (на англ. языке) }\end{array}$ & $\begin{array}{c}\text { Перевод } \\
\text { К. П. Победоносцева } \\
\text { (Гражданинб. 1874. } \\
\text { № 3. С. 78-81) }\end{array}$ & $\begin{array}{c}\text { Редакционное } \\
\text { изложение } \\
\text { (Гражданинъ. 1874. } \\
\text { № 2. С. 37-39) }\end{array}$ & Комментарии \\
\hline $\begin{array}{l}\text { May the benediction of } \\
\text { both Churches and of both } \\
\text { countries rest on the coming } \\
\text { destiny of these two youth- } \\
\text { ful lives henceforth, as we } \\
\text { pray, to be united in the } \\
\text { indissoluble bond of a com- } \\
\text { mon and ever-increasing in- } \\
\text { terest in the same works of } \\
\text { noble and gracious benefi- } \\
\text { cence; the same keen pursuit } \\
\text { of all things pure and true, } \\
\text { lovely and of good report; } \\
\text { the same constant reaching } \\
\text { forward after the high and } \\
\text { holy purposes, whereby } \\
\text { alone families are blessed, } \\
\text { and kingdoms established } \\
\text { and nations exalted! }\end{array}$ & $\begin{array}{l}\text { Благословенія объихъ } \\
\text { церквей и объихъ странъ } \\
\text { да пребываютъ на гря- } \\
\text { дущихъ судьбахъ этихъ } \\
\text { двухъ юныхъ жизней, } \\
\text { да соединятся онъ не- } \\
\text { разрывною связью для } \\
\text { взаимныхъ, неослаб- } \\
\text { ныхъ заботъ объ общемъ } \\
\text { благоденствіи и для не- } \\
\text { усыпнаго стремленія къ } \\
\text { высокимъ и святымъ } \\
\text { цълямъ, которыя охраня- } \\
\text { ютъ семейныя узы, воз- } \\
\text { вышаютъ народы и ут- } \\
\text { верждаютъ государства } \\
\text { и царства! }\end{array}$ & $\begin{array}{l}\text { «Б л а г о с л о в е н і я } \\
\text { объихъ церквей и объихъ } \\
\text { странъ да пребываютъ } \\
\text { на грядущихъ судьбахъ } \\
\text { этихъ двухъ юныхъ жиз- } \\
\text { ней, да соединятся онъ } \\
\text { неразрывною связью } \\
\text { для взаимныхъ, неослаб- } \\
\text { ныхъ заботъ объ общемъ } \\
\text { благоденствіи и для не- } \\
\text { усыпнаго стремленія къ } \\
\text { высокимъ и святымъ } \\
\text { цьлямъ, которыя охраня- } \\
\text { ютъ семейныя узы, воз- } \\
\text { вышаютъ народы и ут- } \\
\text { верждаютъ государства } \\
\text { и царства!» }\end{array}$ & $\begin{array}{l}\text { В переводе Победоносиева } \\
\text { в вылеленном фрагмен- } \\
\text { те отсутствует часть } \\
\text { предложения: «аs we рraу». } \\
\text { Буквально: «отныне, когда } \\
\text { мы молимся» } \\
\text { В переводе Победонос- } \\
\text { цева выделенный фраг- } \\
\text { мент опущен. Дословньй } \\
\text { перевод фрагмента: «да } \\
\text { соединит оно неразрыв- } \\
\text { ной связью для глубоких } \\
\text { поисков всего чистого } \\
\text { и истинного, прекрасных } \\
\text { и добрых отношений». }\end{array}$ \\
\hline $\begin{array}{l}\text { NOTE PAGE } 13 . \\
\text { It appears that Vladimir } \\
\text { Monomachus married, as } \\
\text { his first wife Gytha, or Gyda, } \\
\text { daughter of King Harold bet- } \\
\text { ween the years } 1070 \text { and } \\
\text { 1075, in which latter year his } \\
\text { first son was born who bore } \\
\text { the name of Harold and } \\
\text { married Christiana, daugh- } \\
\text { ter of the King of Sweden. } \\
\text { (See Karamsin: History of } \\
\text { Russia. French Translation. } \\
\text { Vol. II. 211.) }\end{array}$ & \begin{tabular}{|} 
Стр. 13 записей \\
Владимир Мономах, \\
кажется женился на его \\
первой жене Гита (Гида), \\
дочь Короля Гарольда \\
между 1070 и 1075 гг., \\
в браке с которой родился \\
сын, которому дали имя \\
Гарольд и который женил- \\
ся на Кристине, дочери \\
шведского короля (см. Ка- \\
рамзин «история государ- \\
ства Российского. Пер. на \\
фр. Том. ІІ, 211)
\end{tabular} & & \\
\hline
\end{tabular}

\section{ПРИМЕЧАНИЯ}

* Исследование выполнено по гранту Министерства образования и науки России «Новые источниковедческие и текстологические исследования русской словесности XIX-XX вв.» (№ 34.1126). 